\title{
Geochemistry and Pb Isotopic Proof for Sources of Heavy Metal(Loid)s in Late Cretaceous Sandstones From Eastern Pontides (NE Turkey)
}

Çiğdem Saydam Eker ( $\nabla$ csaydam@gumushane.edu.tr)

Gumushane University

\section{Research Article}

Keywords: NE Turkey, Late Cretaceous, Pollution indices, $\mathrm{Pb}$ isotope, Paleoclimate, Redox condition

Posted Date: April 1st, 2021

DOl: https://doi.org/10.21203/rs.3.rs-363683/v1

License: (c) (i) This work is licensed under a Creative Commons Attribution 4.0 International License.

Read Full License

Version of Record: A version of this preprint was published at Environmental Earth Sciences on July 18th, 2021. See the published version at https://doi.org/10.1007/s12665-021-09772-7. 


\title{
Geochemistry and $\mathrm{Pb}$ isotopic proof for sources of heavy metal(loid)s in Late Cretaceous sandstones from Eastern Pontides (NE Turkey)
}

\section{Çiğdem Saydam Eker}

Department of Geology, Engineering and Natural Sciences Faculty, Gumushane University, 29000 Gumushane, Turkey

\begin{abstract}
Upper Cretaceous sedimentary rocks are widely exposed around Trabzon, Giresun and Gümüşhane in the eastern Pontides. The sedimentary rocks are mainly composed of sandstones and marls, and the thicknesses of these rocks range from $170 \mathrm{~m}$ to $400 \mathrm{~m}$. This paper focused on Late Cretaceous sandstones of Trabzon, Giresun and Gümüşhane regions to identify the concentrations, sources, deposition environment and conditions of certain heavy metal(loid)s ( $\mathrm{Zn}, \mathrm{Pb}, \mathrm{Cu}, \mathrm{Ni}, \mathrm{As}, \mathrm{Co}, \mathrm{Mo}$ and V). Enrichment factor (EF), geo-accumulation index (Igeo), Pollution index $(\mathrm{Pi})$, Pollution load index $\left(\mathrm{Pl}_{\mathrm{n}}\right), \mathrm{Pb}$ isotope and multivariate statistical analysis were performed to elucidate the pollution levels and sources. The mean concentrations of $\mathrm{Zn}, \mathrm{Pb}, \mathrm{Cu}, \mathrm{Ni}, \mathrm{As}$, $\mathrm{Co}$, Mo and $\mathrm{V}$ were 16.5, 10.8, 9.4, 13.2, 2.1, 4.4, 0.2 and $21 \mathrm{mg} / \mathrm{kg}$, respectively in the Trabzon area, 35, 5.8,18.8, 102, 3.2, 18.6, 0.5 and $109 \mathrm{mg} / \mathrm{kg}$, respectively in the Giresun area, and 36, 8.9, 14.7, 82, 3.9, 16.9, 0.3 and $106 \mathrm{mg} / \mathrm{kg}$, respectively in the Gümüşhane area. In general, the evaluation indices exhibited that the sandstones were moderately polluted by As in the Trabzon area, and strongly polluted by Ni and As, moderately polluted by Co and V in the Giresun and Gümüşhane areas. The results of multivariate statistical analyses indicated that $\mathrm{As}$ and partly $\mathrm{Pb}$ might be originated from anthropogenic sources, whereas other metals were derived from geogenic origin. Lead isotopic analysis demonstrated two characterized signatures of the pollution sources in the sandstones, one related to geogenic origin and the other to coal, gasoline and pesticides. The sandstones were deposited in transition - marine environment under oxic - weak oxic conditions and paleoclimatic conditions ranged from arid to moist during Late Cretaceous period.
\end{abstract}

Key word NE Turkey, Late Cretaceous, Pollution indices, Pb isotope, Paleoclimate, Redox condition *Corresponding author: csaydam@gumushane.edu.tr, csaydameker@gmail.com (Ç. Saydam Eker)

\section{Introduction}

Sediments are commonly considered as a sink for most heavy metal(loid)s (Singh et al., 2002; Çevik et al., 2009; Saydam Eker and Demirkol Kiliç, 2018; Saydam Eker and Arı 2020a) and they can be a storage for both geogenic and anthropogenic heavy metal(loid)s (Jiao et al., 2015; Wu and Probst 2021). The spread of heavy metal(loid)s to the environment consists of generally through volcanoes, geological weathering, erosion, vehicles exhausts, fertilizers, mining areas, pesticides and industrial activities (Islam et al., 2015, 2018; Tokatlı et al., 2015; Ustaoğlu and Islam, 2020; Ustaoğlu, 2020). Therefore, geochemical features of sediments are usually used to define the sources of pollution owing to heavy metal(loid)s. The accumulation of heavy metal(loid)s is sediments controlled 
by several processes according as the features of the sediments such as organic matter, carbonate and clay mineral contents, pH and redox conditions (Ghrefat and Yusuf, 2006; Du Laing et al., 2009). In additional, grain size distribution of the sediments essentially influences the heavy metal(loid)s concentrations. Some researchers (Ip et al., 2007; Chakraborty et al., 2015; Simonetti et al., 2017; Saydam Eker and Ar1, 2020a, Saydam Eker, 2020a) have recommended that fine grained sediments, such as clay-silt, have higher concentrations of heavy metal(loid)s than coarse-grained sediments. The heavy metal(loid)s distribution in the sediments is controlled by climatic and geomorphologic conditions geochemistry of parent rock, sediments texture, time of weathering, living organism and anthropogenic inputs, such as gasoline combustion, mining, agricultural activities, vehicle exhausts, burning coal and industrial and residential emission (Pinto et al., 2017; Seifi et al., 2019). In general, the high heavy metal(loid) contents in sediments can be good indicator anthropogenic pollution, for high substance heavy metal(loid)s are commonly attributed on terrigenous input and anthropogenic, rather than geogenic sources (Goher, 2014; Saydam Eker and Ar1, 2020a). Environmental pollution by heavy metals, due to a reality of anthropogenic activities such as industrialization, mining, agriculture, urbanization, energy generation and transportation, has increased importantly global and a critical environmental attention that has been menace ecosystem and human health (Vural, 2015; Yousaf et al., 2016a, b; Cheema et al., 2020). For instance, the heavy metal(loid)s like Cd, $\mathrm{Cr}, \mathrm{As}, \mathrm{Pb}$ and $\mathrm{Hg}$ are known systematic toxicants, that can cause a critical threat to environment health and ecosystem (Yousaf et al., 2018). Among these heavy metals, one of the most significant environmental pollutants is $\mathrm{Pb}$ which is fairly toxic even if very little because of its abundance and rapid bioaccumulation (Cheema et al., 2020). Lead in sediments generally originates from many sources such as rocks, gasoline, aerosols, , battery industry and cooler pigment. Additionally, the primary origin of $\mathrm{Pb}$ and As pollutant in sediments are related to atmospheric depositional burning coal, vehicle exhausts and gasoline combustions. Many researchers (e.g. Cheng and Hu, 2010; Lin et al., 2016; Potra et al., 2017; Saydam Eker et al., 2017; Orani et al., 2019; Lermi and Sunkari, 2020) have suggested that $\mathrm{Pb}$ isotopes are beneficial indicator of $\mathrm{Pb}$ contamination sources in sediments/soils and additive ratios of different sources.

In the environment, there are four stable-isotopes $\left({ }^{204} \mathrm{~Pb},{ }^{206} \mathrm{~Pb},{ }^{207} \mathrm{~Pb}\right.$ and ${ }^{208} \mathrm{~Pb}$, Rabinowitz, 1995) and relative abundances of the $\mathrm{Pb}$ isotopes change as regards their geogenic origin (Patel et al., 2008; Cheema et al., 2020). Among these isotopes, ${ }^{206} \mathrm{~Pb},{ }^{207} \mathrm{~Pb},{ }^{208} \mathrm{~Pb}$ are radiogenic, only ${ }^{204} \mathrm{~Pb}$ is non-radiogenic and its abundance on earth is nearly stable (Komárek et al., 2008). A complementary examination of $\mathrm{Pb}$ and other heavy metal(loid)s substances in sediments that are contaminated by anthropogenic activities is a primary approach to determining the degree of pollution or their natural sources.

Late Cretaceous clastic rocks are broadly exposed in the eastern Pontides significantly in Trabzon, Giresun and Gümüşhane region. These rocks are mainly composed of sandstones and marls, rarely claystone, limestone and felsic tuff. Trabzon, Giresun and Gümüşhane, located in northeast Turkey, are places where intensive agricultural activities (include lettuce, potatoes, beans, onions parsley, walnut and apple trees, thus hazelnut is the most growed product of Trabzon and Giresun) and metallic mining activities ( $\mathrm{Pb}-\mathrm{Cu}-\mathrm{Zn}$-Au ores) are performed out and they are also cities of education. Trabzon and Giresun are coastal cities that's way, a temperate marine climate reigns in these areas, where is called Black Sea climate which has cold and wet winters, warm and wet summers. Climate in the Gümüşhane area is step, summer season is a hot and winter is a cold. Therefore, to warm up in all three fields of study area, up to lately coal was burned. The purpose of this study are to: (1) Define the concentrations and vertical change of 8 heavy metal(loid)s ( $\mathrm{Zn}, \mathrm{Pb}, \mathrm{Cu}, \mathrm{Ni}, \mathrm{As}, \mathrm{Co}, \mathrm{Mo}$ and $\mathrm{V}$ ) in the Upper Cretaceous sandstones 
from Trabzon, Giresun and Gümüşhane areas, (2) Evaluate the level of pollution of these metal(loid)s in the sandstones using some pollution index, such as EF, Igeo, $\mathrm{Pi}$ and $\mathrm{Pl}_{\mathrm{n}}$, (3) Examined whether the grain size of the sandstones, paleoclimate, paleo-salinity and redox conditions of the deposition environment affect the abundance of the heavy metal(loid)s, (4) Differentiate the sources of collected $\mathrm{Pb}$ in the sandstones using $\mathrm{Pb}$ isotopes (5) Define the anthropogenic sources of the heavy metal(loid)s.

\section{Study area and geological setting}

Trabzon, Giresun and Gümüşhane areas are located in the northeastern Anatolia within Eastern Pontides orogenic belt which lies within Alpin orogenic belt. The eastern Pontides belt is commonly subdivided into southern and northern parts that change in terms of rock companies The northern part is characterized by Carboniferous to Eocene granitoids and volcanic rocks. The southern part includes metamorphic, volcanic, plutonic and clastic rocks from the Paleozoic to Eocene. The basement rocks of the eastern Pontides are formed of methamorphic rocks of Lower Carboniferous age (Topuz et al, 2004; Ustaömer and Robertson, 2010) and crosscutting Upper Carboniferous granitoids (Topuz et al., 2010; Ustaömer and Robertson, 2010; Dokuz, 2011; Kaygusuz et al., 2012). The Early and Middle Jurassic volcanic volcanoclastic and sedimentary rocks (Conglomerates, sandstones, chert and carbonates) ( Saydam Eker et al., 2012; Saydam Eker and Ar1 2020a, b) lie unconformably on this basement. Upper Jurassic magmatic rocks show an extensive lithological range. Late Jurassic to Middle Cretaceous pelagic and neritic carbonates lie comformably on the Jurassic rocks. Late Cretaceous aged rocks are characterized by turbidites containing mainly sandstones and marls (Saydam, 2002; Saydam and Korkmaz, 2008; Saydam Eker and Korkmaz 2011) and volcanic, granitoids (Sipahi et al., 2018) in the eastern Pontides. Eocene rocks are represented by turbidites (Conglomerates, sandstones and mudstones) (Saydam Eker, 2012; 2013), volcanoclastic and volcanic rocks (Kaygusuz et al., 2011; Aydınçakır, 2014; Akaryalı and Akbulut, 2016) in this region. Quternary units are characterized by alluvium and terraces (Saydam Eker, 2017; 2020 a, b) (Fig. 1).

\section{Materials and methods}

\section{Sampling and preparation}

In this study, a total of six stratigraphic section were measured from Dağbaşı (Trabzon), Çamlyyayla and Evliyatepesi (Giresun), and Musalla, Pirahmet and Mescitli (Gümüşhane) fields. The thickness of the upper Cretaceous sequences was measured as $170 \mathrm{~m}$ in the Dağbaşı (Trabzon) section, $315 \mathrm{~m}$ in the Çamliyayla section, $400 \mathrm{~m}$ in the Evliyatepesi section(Giresun), $210 \mathrm{~m}$ in the Musalla section, $288 \mathrm{~m}$ in the Pirahmet section and 304 $m$ in the Mescitli section (Gümüşhane) (Saydam, 2002; Saydam Eker and Korkmaz, 2011). While measuring stratigraphic sections, a total of 33 sandstone samples (six samples for Dağbaşı section (Trabzon), four samples for Çamliyayla and six samples for Evliyatepesi section (Giresun), seven samples for Musalla, six samples for Pirahmet and four samples for Mescitli section (Gümüşhane) were gathered for geochemistry analysis (Fig. 2). The sandstone sample was about 2000-2500 g. These sandstones were air dried in the laboratory previous to analysis. Additionally, the sandstone samples were homogenized split into sub-samples and crushed to roughly 200 mesh $(0.075 \mathrm{~mm})$ size using an agate mill. 


\section{Laboratory Analysis}

\section{Grain size analysis}

For the well-cemented sandstones, thin sections have to be used and several hundred grain sizes measured with an eyepiece graticule and point counter, as detailed is in McManus (1988).

\section{Physicochemical analysis}

The total organic carbon (TOC) content of the sandstone samples was defined by oxidation with acidified $\mathrm{K}_{2} \mathrm{Cr}_{2} \mathrm{O}_{7}$ and back titration with ferrous ammonium sulphate. They were soaked in water with an aliquot of $10 \%$ sodium hexamtaphosphate solution and lightly agitated for about $1 \mathrm{~h}$ to increase disaggregation. The samples were then washed over an $80 \mu \mathrm{m}$ sieve and oven-dired at a temperature 0 f $60{ }^{\circ} \mathrm{C}$. The percent mud of the samples was calculated by multiplying the mass of the $80 \mu \mathrm{m}$ fraction and the initial sample mass minus water content. The TOC content of sandstones was determined by Bernard calcimeter method (Guitián and Carballas, 1976).

\section{Geochemical analysis}

Major and trace elements were determined on the 33 sandstone samples (6 samples for Trabzon, 10 samples for Giresun and 17 samples for Gümüşhane), at the commercial Acme Analytical Laboratories Ltd (now Bureau Veritas Minerals) in Vancouver, Canada. Major and element (Al2O3, Zn, Pb, Cu, Ni, As, Co, Mo and V) compositions were measured by inductively coupled plasma optical emission spectrometry (ICP-OES) and inductively coupled plasma mass spectrometry (ICP-MS) using $0.2 \mathrm{~g}$ of sediment fused with $1.5 \mathrm{~g}$ of $\mathrm{LiBO}_{2}$ and dissolved in $100 \mathrm{ml}$ of $5 \% \mathrm{HNO}_{3}$. Loss on ignition (LOI) was determined using dried samples heated to a temperature of $1.000{ }^{\circ} \mathrm{C}$ for $15 \mathrm{~min}$. The detection limits were in the range of $0.001 \mathrm{wt} \%$ to $0.1 \mathrm{wt} \%$ for major element oxides and $0.1 \mathrm{ppm}$ to $10 \mathrm{ppm}$ for trace elements and $0.01 \mathrm{ppm}$ for $\mathrm{Hg}$. Calibration and verification standards together with reagent blanks were added to the sample batches. STD SO-18 was certified in-house against 38 certified reference materials, including CANMET SY-4 and USGS AGV-1, G-2, GSP-2, and W-2 as known external standards. The analytical accuracy is better than $4 \%$.

\section{Pb isotope analysis}

Isotopic analysis of $\mathrm{Pb}$ was performed at the commercial Acme Analytical Laboratories Ltd. in Vancouver, Canada. The prepared sample is digested with a modified aqua regia solution of equal parts concentrated $\mathrm{HCl}$, $\mathrm{HNO}_{3}$, and $\mathrm{DI} \mathrm{H}_{2} \mathrm{O}$ for $1 \mathrm{~h}$ in a heating block or a hot water bath. The sample is made up to volume with dilute $\mathrm{HCl}$. Sample splits of $0.5,15$, or $30 \mathrm{~g}$ were analyzed. $\mathrm{Pb}$ isotope add-ons (+ISO) $\mathrm{Pb}_{204}, \mathrm{~Pb}_{206}, \mathrm{~Pb}_{207}$, and $\mathrm{Pb}_{208}$ are suitable for geochemical exploration of $U$ and other commodities where gross differences in natural to radiogenic $\mathrm{Pb}$ ratios are beneficial. Isotope values can be obtained from the concentrations and intensities. Sample splits of $0.5,15$, or $30 \mathrm{~g}$ were analyzed. Pb isotopic analyses were performed on three samples (D1, D17, D21) from 
Trabzon area, five samples (C11, C18, A14, A28, A36) from Giresun area and six samples (N17, N37, N40, R34, M30) from Gümüşhane area.

\section{Assessment of the pollution index}

\section{Enrichment factor (EF)}

EF is commonly used to assist the determination of the level heavy metal(loid) pollution. Furthermore, Thang et al. (2018) suggested that this index is useful in evaluation the anthropogenically introduced heavy metal(loid) and the equation is:

$\mathrm{EF}=\frac{\left(\frac{C i}{\text { Cref }}\right) \text { Sediment sample }}{\left(\frac{B n}{B r e f}\right) U C C}$

Where, $C i$ is the ingredient of the studied element in the sandstone; Cref is the concentration of a reference element (Sc) for normalization objectives, $\mathrm{Bn}$ is the background concentration of the heavy metal(loid) in the upper continental crust (UCC), and Bref is the background concentration of the reference element (Sc) in the UCC (Taylor and McLennan, 1985).

\section{Geo-accumulation index (Igeo)}

Igeo, used initially by Müller (1969; 1981), has been generally used to define the pollution level of heavy metal(loid) in sediments and the equation is:

$\operatorname{Igeo}=\log 2\left[\frac{(\mathrm{Cn})}{(1.5)(B n)}\right]$

Where $C_{n}$ indicates the concentrations of heavy metal(loid) $n$ in the analyzed sample, $B_{n}$ is the reference concentration of the element in the background sample (Wedepohl, 1995) and the factor (1.5) is used to minimize the influence likely changes in the background values, as a result of lithogenic input.

\section{Pollution index $(\mathbf{P i})$ and Pollution load index $\left(\mathrm{Pl}_{\mathbf{n}}\right)$}

$\mathrm{Pi}$ is the ratio of single heavy metal(loid) contents in sediments and the background value. Pi is calculated with the following equation (Cheng et al., 2007):

$\mathrm{Pi}=\frac{C_{n}}{C_{\text {ref }}}$

Where $C_{n}$ is the concentration of the studied heavy metal(loid), Cref is the reference value. 
$\mathrm{Pl}_{\mathrm{n}}$ is used for definition of total heavy metal(loid) pollution in sediments certain site and mean of Pi of all the distinct heavy metal(loid)s present in the study areas (Tomlinson et al., 1980; Rana et al., 2016; Raj et al., 2019). $\mathrm{Pl}_{\mathrm{n}}$ is calculated with the following formula (Cheng et al., 2007):

$\mathrm{PI}_{\mathrm{n}}=\sqrt{ } \frac{(\mathrm{Pi})^{2} \max +\left(\frac{1}{\mathrm{n}} \sum_{i=1}^{n} P i\right)^{2}}{2}$, 4

Where $\mathrm{Pi}$ is the monomial pollution index of heavy metal(loid), (Pi)max is the maximum value of the monomial pollution indices of all heavy metal(loid)s.

\section{Multivariate statistical analysis}

Pearson's correlation matrix (PCM) and principial component (PCA) was used to decode the interrelations among heavy metal(loid)s and physicochemical parameters. These analyses were applied with a statistical software SPSS 22.0. PMC analysis commonly determined the relation among the heavy metal(loid)s and verified the conclusions of multivariate analysis (Tahri et al., 2005; Liao et al., 2017). In addition, this analysis as used to understand pollution sources (anthropogenic and geogenic).

\section{Results}

\section{Heavy metal/metalloid concentrations in the sandstones}

Concentrations of the some major, trace elements, heavy metal (loid) and TOC and Mz values were presented in the Table 1. Grain size average of the studied samples range from $0.5-2 \phi$ in the Trabzon area, $1.2-2.2 \phi$ in the Giresun area and $0.78-2.51 \phi$ in the Gümüşhane area (Saydam 2002; Saydam Eker and Korkmaz 2011). The sandstones are coarse to medium-grained using the Wentworth scale in the Trabzon area, medium to fine-grained in the Giresun and coarse to fine grained in the Gümüşhane.

The mean concentrations of heavy metal(loid) $(\mathrm{mg} / \mathrm{kg})$ varied in the order of $\mathrm{V}(21)>\mathrm{Zn}(16.5)>\mathrm{Ni}(13.2)>$ $\mathrm{Pb}(10.8)>\mathrm{Cu}(9.4)>\mathrm{Co}(4.4)>\mathrm{As}(2.1)>\mathrm{Mo}(0.2)$ in the Trabzon region, $\mathrm{V}(109.1)>\mathrm{Ni}(102.3)>\mathrm{Zn}(34.5)$ $>\mathrm{Cu}(18.8)>\mathrm{Co}(18.6)>\mathrm{Pb}(5.8)>\mathrm{As}(3.2)>\mathrm{Mo}(0.5)$ in the Giresun region and $\mathrm{V}(106)>\mathrm{Ni}(81.7)>\mathrm{Zn}(36.1)$ $>\mathrm{Co}(16.9)>\mathrm{Cu}(14.7)>\mathrm{Pb}(8.9)>\mathrm{As}(3.9)>\mathrm{Mo}(0.3)$ in the Gümüşhane region. The highest mean of TOC value (7.7\%) was found in the Trabzon region, followed by Gümüşhane region (2.7\%) and Giresun region (2.6\%). The heavy metal(loid) concentrations in sediments from Trabzon, Giresun and Gümüşhane areas were summarized in Table 1, Fig. 3. The highest V (155 mg/kg), Zn (76 mg/kg), Pb (29.5 mg/kg), Cu (20.7 mg/kg), Ni (140.9 mg/kg), As $(8.7 \mathrm{mg} / \mathrm{kg})$, Co (29.2) values were measured in the Gümüşhane area, and the highest Mo (0.8) value was measured in the Giresun and Gümüşhane areas. The lowest $\mathrm{Zn}(4.5 \mathrm{mg} / \mathrm{kg}), \mathrm{Pb}(3.5 \mathrm{mg} / \mathrm{kg}), \mathrm{Cu}(2.7 \mathrm{mg} / \mathrm{kg})$ values were measured in the Gümüşhane, the lowest Ni $(8.8 \mathrm{mg} / \mathrm{kg})$, As $(0.4 \mathrm{mg} / \mathrm{kg})$ and Co $(2.3 \mathrm{mg} / \mathrm{kg})$ values were measured in the Trabzon area. The $\mathrm{Cu}, \mathrm{Zn}, \mathrm{Pb}$ and $\mathrm{Mn}$ in the Gümüşhane region showed a wide variation range owing to low and high values, whereas all the heavy metal(loid) in the Giresun showed a narrow variation range. Figure 4 indicated the vertical distributions of the heavy metal(loid)s normalized to the UCC (Taylor and McLennan, 1985). The result indicated that three samples (D12, D16 and D21) of the Dağbaşı (Trabzon) section 
were enriched in As, one sample (D21) was slightly enriched in $\mathrm{Pb}$, depleted in other heavy metals. All of the Çamllyayla (Giresun) samples were enriched in Ni, As and V, and depleted in other metals; Evliyatepesi (Giresun) samples were enriched in Ni, As, Co and V, depleted in other metals. All of the Musalla, Mescitli and Pirahmet (Gümüşhane) samples were enriched in Ni (except R34 for Pirahmet), As (except R36 for Pirahmet), V and Co (except R34 for Pirahmet), depleted in other metals. The heavy metal(loid) abundance of the samples was not significant relationship of the thickness of the upper Cretaceous sequences. In addition, the heavy metal(loid) composition of the studied sandstones was not importantly influenced by the grain size of the sandstones (except $\mathrm{Zn}, \mathrm{Ni}, \mathrm{Co}, \mathrm{Mo}$ and $\mathrm{V}$ in the Trabzon area).

\section{Pollution assessment of heavy metal(loid)s}

\section{Enrichment factor (EF)}

Table 2 indicated the descriptive statistics of EF for eight heavy metal(loid)s in all studied sandstone samples and average upper continental crust (UCC) values (Taylor and McLennan 1985). The means of EF were in the order of $\mathrm{Mo}<\mathrm{Zn}<\mathrm{V}<\mathrm{Cu}<\mathrm{Co}<\mathrm{Pb}=\mathrm{Ni}<$ As in the Trabzon area, $\mathrm{Pb}<\mathrm{Mo}<\mathrm{Zn}<\mathrm{Cu}<\mathrm{Co}=\mathrm{V}<\mathrm{As}<\mathrm{Ni}$ in the Giresun area and $\mathrm{Mo}<\mathrm{Zn}<\mathrm{Cu}=\mathrm{Pb}<\mathrm{Co}=\mathrm{V}<\mathrm{As}<\mathrm{Ni}$ in the Gümüşhane area. A threshold of 2 was admitted to descriptive whether a definite metal was enriched in soil. If a local reference element is used to compute EF, this threshold could be decreased to 1.5 (Hernandez et al., 2003; Roussiez et al., 2005; N'guessan et al., 2009; Benabdelkader et al., 2018; Wu and Probst, 2021). The mean EF of the Ni for Giresun area and As, Ni for Gümüşhane area were higher than the threshold of 2. In the Trabzon area, As for D12 and D21 samples was higher than threshold (Fig. 5a). In the Giresun area, As for C18 and A14 samples, Ni for all samples were higher than threshold (Fig. 5b). In the Gümüşhane area, Co for N3 sample, Pb for R34, As for N17, N33, N37, N40, R15, R31, R34, M30 and M33, and Ni for about all samples (except N50, R34, M30 and M33) were higher than threshold (Fig. 5c). The EF values of Mo had been calculated as very low in all the studied samples.

\section{Geo-accumulation index (Igeo)}

Table 3 showed the Igeo value of six heavy metal(loid)s, average background values, Igeo value and class and pollution level. The mean values of Igeo were in order of $\mathrm{Zn}<\mathrm{V}<\mathrm{Co}<\mathrm{Pb}<\mathrm{Cu}<\mathrm{Ni}<\mathrm{As}$ in the Trabzon area, $\mathrm{Pb}<\mathrm{Zn}<\mathrm{Cu}<\mathrm{As}<\mathrm{Co}<\mathrm{V}<\mathrm{Ni}$ in the Giresun area, $\mathrm{Pb}<\mathrm{Zn}<\mathrm{Cu}<\mathrm{Co}<\mathrm{As}<\mathrm{V}<\mathrm{Ni}$ in the Gümüşhane area. The values of Igeo for all of the heavy metal(loid)s (except max Igeo value for As) were negative in the Trabzon area, indicating that the sandstones were unpolluted by these metal(loid)s (Fig. 6a). The mean values of Igeo for $\mathrm{Zn}, \mathrm{Pb}, \mathrm{Cu}$ were negative, for $\mathrm{Ni}$ (1.66 to 1.87, with a mean of 1.82 ), $\mathrm{V}$ (0.30 to 0.62 , with mean of 0.46$)$, As (-0.58 to 0.82 , with a mean of 0.08$)$ and $\mathrm{Co}(-0.26$ to 0.26 , with a mean of 0.10 ) were positive in the Giresun area, indicating that the sandstones were polluted by $\mathrm{Ni}, \mathrm{V}$, As and $\mathrm{Co}$ (unpolluted to moderately polluted by $\mathrm{V}$, As, Co and moderately polluted by $\mathrm{Ni}$ ), and unpolluted by $\mathrm{Zn}, \mathrm{Pb}, \mathrm{Cu}$ (Fig. 6b). The mean values of Igeo for $\mathrm{Ni}$ ( -0.70 to 2.33 , with a mean of 1.51), As (-0.58 to 1.83, with a mean of 0.50$)$ and $\mathrm{V}$ (-1.03 to 0.96 , with mean of 0.42 ) were positive, $\mathrm{Zn}$, $\mathrm{Pb}, \mathrm{Cu}$ and $\mathrm{Co}$ were negative in the Gümüşhane area, indicating that the sandstones were polluted by $\mathrm{Ni}$, As and $\mathrm{V}$ (unpolluted to moderately polluted by $\mathrm{As}, \mathrm{V}$ and moderately polluted by $\mathrm{Ni}$ ), and unpolluted by $\mathrm{Zn}, \mathrm{Cu}, \mathrm{Co}$ and 
$\mathrm{Pb}$ (Fig. 6c). In additionally, Fig. 5d showed that the sandstones in the Giresun and Gümüşhane areas were polluted by $\mathrm{Ni}$ in approximately same amount.

\section{Pollution index (Pi) and Pollution load index $\left(\mathrm{Pl}_{\mathbf{n}}\right)$}

The Pi rates of the heavy metal(loid) of the sandstones in the Trabzon area exhibited unpolluted to low polluted and varied as: $\mathrm{Zn}(0.19$ to 0.58 , with mean of 0.32$), \mathrm{Pb}(0.35$ to 1.23 , with mean of 0.63$), \mathrm{Cu}(0.29$ to 1.26 , with mean of 0.65$)$, $\mathrm{Ni}(0.47$ to 1.01 , with mean of 0.71$)$, As ( 0.20 to 1.90 , with mean of 1.03$)$, Co (0.20 to 0.72 , with mean of 0.38 ) and V (0.15 to 0.92 , with mean of 0.40$)$ (Table 4, Fig. 7a). The Pi values of the heavy metal(loid) of the sandstones in the Giresun and Gümüşhane areas indicated unpolluted to strongly polluted and varied as: $\mathrm{Zn}$ ( 0.56 to 0.75 and 0.40 to 1.46 , with mean of 0.66 and 0.72 , respectively), $\mathrm{Pb}$ ( 0.24 to 0.43 and 0.21 to 1.74 , with mean of 0.74 and 0.54 , respectively ), $\mathrm{Cu}$ (1.11 to 1.44 and 0.19 to 1.45 , with mean of 1.31 and 1.01 , respectively), $\mathrm{Ni}$ (4.76 to 6.10 and 1.22 to 7.58 , with mean of 5.50 and 4.26, respectively), As (1.20 to 2.65 and 1.00 to 5.35 , with mean of 1.59 and 2.12, respectively), Co (1.47 to 1.79 and 0.58 to 2.52, with mean of 1.60 and 1.43 , respectively ) and V (1.91 to 2.30 and 0.74 to 2.92 , with mean of 2.06 and 2.01, respectively (Table 4, Figs. 7b, c).

In the Trabzon area, $\mathrm{Pl}_{\mathrm{n}}$ values of $\mathrm{Zn}, \mathrm{Pb}, \mathrm{Ni}, \mathrm{Co}$ and $\mathrm{V}$ were below 1 (0.47, 0.98, 0.87 and 0.58, respectively), indicating that the sandstones were unpolluted by these metals, and $\mathrm{Cu}$ and As were between 1 and $2(1.0$ and 1.53 , respectively), indicating that the sandstones were low polluted by $\mathrm{Cu}$ and $\mathrm{As}$ (Table 5, Fig. 7d). The $\mathrm{Pl}_{\mathrm{n}}$ values of the sandstones in the Giresun area varied from 0.39 to 5.81. These sandstones were unpolluted by $\mathrm{Zn}$ and $\mathrm{Pb}(0.71$ and 0.39 , respectively), low polluted by $\mathrm{Cu}$ and $\mathrm{Co}$ (1.38 and 1.70, respectively), moderately polluted by As (2.18), V (2.18) and strongly by $\mathrm{Ni}$ (5.81) (Table 4, Fig. 7d). In the Gümüşhane area, $\mathrm{Pl}_{\mathrm{n}}$ values of $\mathrm{Zn}, \mathrm{Pb}$ and $\mathrm{Cu}$ were between 1 and $2(1.15,1.29$ and 1.25 , respectively), indicating that the sandstones were low polluted by these metals, Co and V were between 2 and 3 (2.05 and 2.51, respectively), indicating that the sandstones were moderately polluted by $\mathrm{Co}, \mathrm{V}$, and $\mathrm{As}$ and $\mathrm{Ni}$ were above 3 (4.07 and 6.15, respectively), indicating that the sandstones were strongly polluted by As and Ni (Table 4 and Fig. 7d).

\section{Lead isotopic tracing in the sandstone}

Lead isotopes provide an effective tool for determining the pathways and sources of $\mathrm{Pb}$ pollution because the isotopic composition of $\mathrm{Pb}$ is not importantly impressed by physico-chemical fractionation processes (Bollhöfer and Rosman 2001; Veysseyre et al., 2001; Komárek et al., 2008). Therefore, Pb isotope analysis is often used to define whether content of metals in sediments of anthropogenic or geogenic. Lead in sediments is possibly a mixture of natural lead from the weathering of host rocks and anthropogenic $\mathrm{Pb}$. Lead is present in widespread various rock kinds range from about $30 \mathrm{mg} / \mathrm{kg}$ to $1 \mathrm{mg} / \mathrm{kg}$ among igneous rocks, black shale, evaporitic rocks, rhyolite and granitic rocks, respectively (Wedepohl 1995; Cheeme et al., 2020). These rocks included radioactive elements have high concentrations of $\mathrm{Pb}$ than sedimentary rock. In same time, sedimentary rocks also include $\mathrm{Pb}$ contents ranging from $10 \mathrm{mg} / \mathrm{kg}$ to $20 \mathrm{mg} / \mathrm{kg}$ (Lovering, 1969; Cheema et al. 2020). Additionaly, the main origin of $\mathrm{Pb}$ pollution in sediments is the metal coating, leather whipping, burning coal and fossil fuels, waste pyromania 
and paint factories (Kushwaha et al., 2018; Ullah et al., 2017; Yousaf et al., 2017; Cheema et al., 2020). Due to the direct release of $\mathrm{Pb}$ from atmospheric deposition or anthropogenic sources $\mathrm{Pb}$ enriched in sediment. In this context, anthropogenic enrichment of $\mathrm{Pb}$ distributes natural life primary by human activities. Lead isotopes as ratios ${ }^{206} \mathrm{~Pb} /{ }^{204} \mathrm{~Pb},{ }^{206} \mathrm{~Pb} /{ }^{207} \mathrm{~Pb}$ and ${ }^{208} \mathrm{~Pb} /{ }^{206} \mathrm{~Pb}$ are commonly used in environmental sciences. ${ }^{206} \mathrm{~Pb} /{ }^{207} \mathrm{~Pb}$ is calculated precisely and present abundantly, that's way, it got more significance and scientist attractiveness among them (Komárek et al., 2008).

The $\mathrm{Pb}$ isotopic ratios of the sandstones ranged from 18.619 to $19.350,19.067$ to 20.277 and 18.979 to 10.952 for ${ }^{204} \mathrm{~Pb} /{ }^{206} \mathrm{~Pb}, 1.182$ to $1.221,1.167$ to 1.237 and 1.191 to 1.231 for ${ }^{206} \mathrm{~Pb} /{ }^{207} \mathrm{~Pb}, 2.069$ to 2.099 , and 2.062 to 2.076 and 2.042 to 2.080 for ${ }^{208} \mathrm{~Pb} /{ }^{206} \mathrm{~Pb}$ in the Trabzon, Giresun and Gümüşhane areas, respectively (Table 5). A plot of the ${ }^{206} \mathrm{~Pb} /{ }^{207} \mathrm{~Pb}$ and ${ }^{208} \mathrm{~Pb} /{ }^{206} \mathrm{~Pb}$ compositions indicated that most of the sandstone samples were located in the natural $\mathrm{Pb}$ area and three samples in the U.S. gasoline and coal from Central European areas (Fig.8a). In the same way, the bulk $\mathrm{Pb}$ content stated as $1 / \mathrm{Pb}$ normalized values and the ${ }^{206} \mathrm{~Pb} /{ }^{207} \mathrm{~Pb}$ ratios (Lermi and Sunkari, 2020) showed that no $\mathrm{Pb}$ pollution of the samples and that present $\mathrm{Pb}$ originated from aerosol, gasoline and geogenic sources (Fig. 8b).

\section{Multivariate statistical analyses}

Factor analysis (FA) and Pearson's correlation matrix (PCM) using principial component analysis (PCA) were applied in this study. Pearson correlation analysis results were given in the Table 6 . In the Trabzon area, the concentrations of $\mathrm{Al}$ were negatively correlated with that of the other heavy metal(loid)s at the $\mathrm{p}<0.05$ level and with TOC at the $\mathrm{p}<0.01$ level. TOC was positively correlated with $\mathrm{Zn}, \mathrm{Pb}, \mathrm{Cu}, \mathrm{Ni}, \mathrm{Co}$ at the $\mathrm{p}<0.05$ level, indicating that the distribution of these elements is controlled by organic matter, $\mathrm{Mz}$ was positively correlated with $\mathrm{Zn}, \mathrm{Ni}$, Co, Mo and $\mathrm{V}$ at the $\mathrm{p}<0.05$, exhibiting that distribution of the elements is controlled by grain size. In the Giresun area, $\mathrm{Al}$ was positively associated with $\mathrm{Zn}, \mathrm{Ni}$ at the $\mathrm{p}<0.01$ and $\mathrm{Cu}$ at the $\mathrm{p}<0.05$ level and negatively associated with TOC at the $\mathrm{p}<0.05$ and Mz, showing that the distribution of these heavy metals is mainly controlled by clay minerals. TOC and Mz were negatively correlated with $\mathrm{Zn}, \mathrm{Cu}(\mathrm{p}<0.05), \mathrm{Ni}(\mathrm{Ni}<0.05)$ and $\mathrm{Mo}$, and $\mathrm{Mz}$ exhibited a positive correlated with TOC at the $\mathrm{p}<0.05$ level. In the Gümüşhane area, the concentrations of $\mathrm{Al}$ showed a positive correlation with $\mathrm{Zn}$ at the $\mathrm{p}<0.05$ level, but there were no correlations with that of the other heavy metal(loid)s. The concentrations of $\mathrm{Ni}$ were a significantly positive correlated with $\mathrm{Co}$, Mo and $\mathrm{V}$ at the $\mathrm{p}<0.01$ level, and Co exhibited a positive corelated with Mo and V at the $\mathrm{p}<0.01$ level. Thus, the concentrations of TOC and $\mathrm{Mz}$ were not correlated with that of the other heavy metal(loid)s (Table 6).

The results of PCA by application varimax rotation for heavy metal(loid)s and their component plots in rotated space was exhibited in the Table 7. The first three PCA defined $92.71 \%, 80.58 \%$ and $74.40 \%$ of the data's variances in the Trabzon, Giresun and Gümüşhane areas, respectively. The PC1, PC2 and PC3 primary included $\mathrm{Zn}, \mathrm{Cu}, \mathrm{Ni}, \mathrm{Co}, \mathrm{V}, \mathrm{Mz}$, and Pb, TOC, and Mo, As, respectively in the Trabzon area (49,69\%, 28.17\% and $14.85 \%$ of the total variance, respectively), $\mathrm{Al}, \mathrm{Cu}, \mathrm{Pb}, \mathrm{Ni}$, and $\mathrm{Zn}, \mathrm{As}, \mathrm{Co}$, and $\mathrm{V}$, respectively in the Giresun area (46.24\%, $19.71 \%$ and $14.62 \%$ of the total variance, respectively), and $\mathrm{Ni}, \mathrm{Co}, \mathrm{Mo}, \mathrm{V}$, and $\mathrm{Al}, \mathrm{Zn}$, and $\mathrm{Cu}$, respectively in the Gümüşhane area $(37.66 \%, 22.16 \%$ and $14.58 \%$ of the total variance, respectively) (Table 7 , Figs. 9a, b, c). 


\section{Discussion}

\section{Source identification}

It is known that heavy metal(loid)s originated from both anthropogenic and natural sources. In accordance with, the $\mathrm{EF}$, Igeo, $\mathrm{Pi}$ and $\mathrm{Pl}_{\mathrm{n}}$ values and multivariate statistical analyses, the results suggested two main sources of these metals/metalloid: (1) all the heavy metal(loid)s (except As) in the Trabzon area, $\mathrm{Zn}, \mathrm{Pb}, \mathrm{Cu}, \mathrm{Co}$ and Mo in the Giresun area, $\mathrm{Zn}, \mathrm{Pb}, \mathrm{Cu}$ and $\mathrm{Mo}$ in the Gümüşhane area mainly originated from natural sources, as their EF, Igeo, $\mathrm{Pi}$ and $\mathrm{Pl}_{\mathrm{n}}$ values were lower than threshold values; (2) According to the $\mathrm{EF}$, Igeo, $\mathrm{Pi}$ and $\mathrm{Pl}_{\mathrm{n}}$ values; the sandstones samples in the Trabzon area were partially polluted by As, in the Giresun area were significantly polluted by Ni, partially polluted by As and V, and in the Gümüşhane area were significantly polluted by Ni and As, partially polluted by $\mathrm{V}$ and $\mathrm{Co}$. However, the concentrations of the Ni were significantly correlated with that of the $\mathrm{Al}, \mathrm{Zn}$, $\mathrm{Cu}$ in the Giresun, and $\mathrm{Co}, \mathrm{Mo}, \mathrm{V}$ in the Gümüşhane area. On account of this, Ni, V and Co were probably originated from natural sources. With respect to $\mathrm{Sc} / \mathrm{Th}$ vs $\mathrm{Co} / \mathrm{Th}$ diagram, which is commonly used to separate between the felsic and the mafic sources of the sandstones (Das et al., 2008; Singh, 2010; Peng et al., 2011; Fang et al., 2021), the sandstones samples were mainly plotted in the mafic field (Fig. 10). In this context, Co, V and Ni enrichment may have occurred due to mafic source rocks. (3) The concentrations of As were a positive correlated with $\mathrm{Pb}$ and $\mathrm{Mo}$ in the Giresun area, and with $\mathrm{Pb}$ in the Gümüşhane area, likely indicating that anthropogenic sources, such as coal and gasoline combustion.

When ${ }^{206} \mathrm{~Pb} /{ }^{207} \mathrm{~Pb}$ ratio is plotted relative to ${ }^{208} \mathrm{~Pb} /{ }^{206} \mathrm{~Pb}$ ratio, it can show general trend that can be used to describe $\mathrm{Pb}$ pollution sources (Monna et al., 2000; Potra et al., 2017). In such diagrams, if the data constitutes several groups, multiple $\mathrm{Pb}$ sources can be extract and linear inclinations mean mixed $\mathrm{Pb}$ sources. However, if the data constitutes a group, only one source of $\mathrm{Pb}$ can be invited (Hurst et al., 1996). According to ${ }^{206} \mathrm{~Pb} /{ }^{207} \mathrm{~Pb}$ vs ${ }^{208} \mathrm{~Pb} /{ }^{206} \mathrm{~Pb}$ diagram, majority of the samples were located in the natural source field, and one sample each from the Trabzon Giresun and Gümüşhane areas located in the fields of U.S. gasoline (Teutsch et al., 2001) and Central Europe coal (Novak et al. 2003), and one sample each from the Trabzon and Giresun areas located away from the identified $\mathrm{Pb}$ sources (Fig. 8a) and these probably originated from other rare sources. The diagram of the 1/Pb normalized values and ${ }^{206} \mathrm{~Pb} /{ }^{207} \mathrm{~Pb}$ ratios also confirmed the above (Fig. 8b). In this diagram, all the samples were clustered in geogenic + aerosol + gasoline originated lead field. Additionally, the concentrations of $\mathrm{Pb}$ were a positive correlated with As in the Gümüşhane and Giresun areas, indicating that the source of As could be coal burning and gasoline combustion. The study area (Dağbaşı) in Trabzon region is sparsely populated and intensive farming activity. On account of this, besides burning coal unconscious use of fertilizers, insecticide and weed killers during farming activities may have also caused partially As enrichment in this sandstones. The studied areas (Çamliyayla and Evliyatepesi) in Giresun and (Musalla, Pirahmet and Mescitli) in Gümüşhane were where the human population more intense than Dağbaşı (Trabzon), so the source of As could be burning coal and gasoline combustion. The enrichment of As in these areas was primary about atmospheric deposition of burning coal and gasoline combustion. The As in the atmosphere, likely amalgamated studied sediments with rainwater, and this element was filtered through porous sandstones and gathered in places. 


\section{Characteristics of depositional environment of the heavy metal(loid)s}

\section{Paleoclimate conditions}

The concentrations of some trace and major elements in the sedimentary rocks indicate the paleoclimates changes (Hu et al., 2017). For instance, Ni, Mn, Fe, Cr and V are relatively enriched under moist climate conditions, whereas $\mathrm{Mg}, \mathrm{Sr}, \mathrm{K}, \mathrm{Ba}, \mathrm{Na}$ and $\mathrm{Ca}$ are enriched under arid climate conditions (Cao et al., 2012). C-value as proxy for climatic prosses has been applied in previous studies $(\mathrm{C}$-value $=\Sigma(\mathrm{Fe}+\mathrm{Mn}+\mathrm{Cr}+\mathrm{Ni}+\mathrm{V}+\mathrm{Co}) /$ $\Sigma(\mathrm{Ca}+\mathrm{Mg}+\mathrm{Na}+\mathrm{K}+\mathrm{Sr}+\mathrm{Ba})$ ) (Zhao et al., 2007; Fu et al., 2016; Wang et al., 2017; Vd'ačný et al., 2019; Bal Akkoca et al., 2019; Saydam Eker, 2020b). The C-values for the Trabzon area range from 0.03 and 0.11 (on mean 0.06), for the Giresun area range from 0.34 and 0.61 (on mean 0.50), for Gümüşhane area range from 0.09 and 1.24 (on mean 0.46) (Table 1). The $\mathrm{C}$-values indicated arid paleoclimate conditions for the Trabzon area, semiarid to semimoist paleoclimate conditions for the Giresun area and arid to moist paleoclimate conditions for the Gümüşhane area (Fig. 11). The highest concentrations of heavy metal(loid)s were measured in the Gümüşhane area, followed by Giresun and Trabzon areas (Fig. 11). It is meant that the heavy metal(loid)s deposited more in humid climatic conditions than arid climatic conditions.

\section{Paleo-redox conditions}

The content and ratio of some redox-sensitive trace elements (e.g. Ni, Th, Mo, V, Co, U and V/(V+Ni), Ni/Co, $\mathrm{Th} / \mathrm{U}$ ) can determine redox conditions of clastic rocks (Yarincik et al., 2000; Lewan and Maynard, 1982; Jones and Manning, 1994; Algae and Maynard, 2004). In sediments, $U$ is depleted under oxidizing conditions and enriched under reducing conditions, while Th is not influenced by redox conditions (Kimura and Watanabe, 2001). $\mathrm{U} / \mathrm{Th}$ ratio is lower than 0.75 , pointing out an oxidation environment, U/Th ratios are between 0.75 and 1.25 , reflecting a weak oxidation environment, and a ratio > 1.25 points to a reducing environment (Jones and Manning, 1994) (Table 8). The U/Th ratios ranged from 0.47 to 0.86 (on mean 0.67 ) in the samples of Trabzon area, pointing out an oxidation - weak oxidation environment, 0.23 - 0.36 (on mean 0.29) in the samples of Giresun area, pointing out an oxidation environment and $0.24-0.83$ (on mean 0.33 ) (Table 1) in the samples of Gümüşhane area, pointing out an oxidation - weak oxidation environment (Table 8). It is known that $\mathrm{V}$ is a redox-sensitive chemical element with a trend to be lesser concentrated in sediments principial oxic water (Lewan and Maynard, 1982). Thus, Mo content, $\mathrm{Ni} / \mathrm{Co}$ and $\mathrm{V} /(\mathrm{V}+\mathrm{Ni})$ ratios were used as paleo-redox proxies for defining the redox conditions (Vd'ačný et al., 2019). Wang et al. (2017) suggested that Ni/Co ratios $<5$ reflect an oxidation environment, range from 5 to 7 , pointing out a weak oxidation environment, and $>7$ reflect a reducing environment. $\mathrm{V} /(\mathrm{V}+\mathrm{Ni})$ ratio $<0.6$ exhibits an oxidation environment, $0.64-0.84$ indicates a weak oxidation environment, and >0.84 implies reducing environment (Feng et al., 2017) (Table 8). V/(V+Ni) and Ni/Co ratios of the analyzed samples varied from 0.4 to 0.72 (on mean 0.54 ) and 2.71 to 5.22 (on mean 3.36), respectively for Trabzon, and 0.49 to 0.56 (on mean 0.52 ) and 4.83 to 6.67 (on mean5.53), respectively for Giresun, and 0.48 to 0.70 (on mean 0.58 ) and 2.07 to 6.30 (on mean 4.66) (Table 1), respectively for Gümüşhane area, indicating that samples for each areas also were deposited under oxidation - weak oxidation conditions (Table 8). The bivariate plots of Ni/Co vs Mo and Ni/Co vs $\mathrm{V}(\mathrm{V}+\mathrm{Ni}$ ) (Fig. 12a, b) confirmed oxic and weak oxic conditions during deposition for the analyzed samples. 


\section{Paleo-salinity}

Paleo-salinity is a significant cursor of the depositional environment because the salinity of ancient water is determined by paleo-salinity degree. The ratio and concept of some elements such as $\mathrm{Sr} / \mathrm{Ba} \operatorname{and}^{\log ^{\mathrm{m}}}$ $\left(\mathrm{Log}\left(100 \mathrm{x}\left(\mathrm{MgO} / \mathrm{Al}_{2} \mathrm{O}_{3}\right)\right)\right.$ (Jones and Manning, 1994) can define the marine and continental facies of depositional environment and paleo-salinity (Li et al., 2020). $\log ^{\mathrm{m}}$ value and $\mathrm{Sr} / \mathrm{Ba}$ ratio decrease from marine to continental facies. The $\log ^{\mathrm{m}}$ value $<0$ indicates nonmarine facies, while $0-1$ represents transition facies, and $>1$ shows marine facies (Jones and Manning, 1994). Wang et al. (2017) suggested that the $\mathrm{Sr} / \mathrm{Ba}<0.6$ represents nonmarine facies, $0.6-1.0$ indicates transition facies, and > 1.0 represents marine facies (Table 8 ). The $\mathrm{Sr} / \mathrm{Ba}$ ratios varied from 0.94 to 10.3 (0n mean 4.9) in the Trabzon area, 0.88 to 1.72 (on mean 1.43) in the Giresun area, and 0.26 and 2.11 (on mean 1.20) (Table 1) in the Gümüşhane area, implying that all three of the study areas were transition - marine facies with brackish - saline water (Table 8). The $\log ^{\mathrm{m}}$ values in the Trabzon and Giresun areas ranged from 1.24 to 1.77 (on mean 1.52) and 1.49 to 1.60 (on mean 1.55), respectively, indicating marine facies with saline water for both areas, and in the Gümüşhane area ranged from 0.81 to 1.61 (on mean 1.42) (Table 8), implying transition - marine facies with brackish - saline water (Table 8) for this area.

\section{Conclusions}

In this paper, the concentrations of heavy metal(loid)s ( $\mathrm{Zn}, \mathrm{Pb}, \mathrm{Cu}, \mathrm{Ni}, \mathrm{As}, \mathrm{Co}, \mathrm{Mo}$ and $\mathrm{V})$, mean grain size ( $\mathrm{Mz}$ ) and TOC were analyzed in the Late Cretaceous aged sandstones collected from Trabzon, Giresun and Gümüşhane areas (Eastern Pontides).

The mean concentrations of the heavy metal(loid) followed in the descending order of $\mathrm{V}>\mathrm{Zn}>\mathrm{Ni}>\mathrm{Pb}>\mathrm{Cu}>\mathrm{Co}>\mathrm{As}>\mathrm{Mo}$ in the Trabzon area, $\mathrm{V}>\mathrm{Zn}>\mathrm{Ni}>\mathrm{Cu}>\mathrm{Co}>\mathrm{Pb}>\mathrm{As}>\mathrm{Mo}$ in the Giresun area, $\mathrm{V}>\mathrm{Zn}>\mathrm{Ni}>\mathrm{Cu}>\mathrm{Co}>\mathrm{Pb}>\mathrm{As}>\mathrm{Mo}$ in the Gümüşhane area. According to mean EF values, all heavy metal(loid)s were not enriched in the sandstone samples for Trabzon area, Ni was enriched in the samples for Giresun area and As and Ni for Gümüşhane area. According to Igeo values, the sandstones was unpolluted - moderately polluted by $\mathrm{As}$ in the studied three sites. $\mathrm{Pl}_{\mathrm{n}}$ values indicated that investigated sandstones were low polluted by $\mathrm{As}$ and $\mathrm{Cu}$ for Trabzon area, low polluted by $\mathrm{Cu}$ and $\mathrm{Co}$, moderately polluted by As, and strongly polluted by Ni for Giresun area, and low polluted by $\mathrm{Zn}, \mathrm{Pb}$ and $\mathrm{Cu}$, moderately polluted by $\mathrm{Co}$ and $\mathrm{V}$, strongly polluted by $\mathrm{Ni}$ and $\mathrm{As}$ for Gümüşhane area.

The results of multivariate statistical analyses in the samples indicated that the accumulation of $\mathrm{Zn}, \mathrm{Cu}, \mathrm{Ni}, \mathrm{Co}$, $\mathrm{V}$, Mo and mostly $\mathrm{Pb}$ was derived from geogenic sources, whereas As and partly $\mathrm{Pb}$ (for Gümüşhane and Giresun) might be derived from anthropogenic sources (atmospheric deposit for Giresun and Gümüşhane, agriculture for Trabzon). $\mathrm{Pb}$ isotopic tracing supported multivariate analysis results. Lead isotopic analysis indicated that two signatures related to the sources of heavy metal(loid); first signature indicated that natural $\mathrm{Pb}$ was the main sources and second signature showed that anthropogenic $\mathrm{Pb}$ was the minor sources including atmospheric deposits (coal burning, gasoline combustion and aerosol) and may be agriculture activities.

Paleoclimate index showed arid climatic conditions for Trabzon area, semiarid to semimoist climatic conditions for Giresun area and arid to moist climatic conditions for Gümüşhane area during deposition of the studied 
sandstones. These sandstones were deposited oxic - weak oxic water column and in the transition - marine environment. According to the data obtained in this study, heavy metal(loid)s accumulated more in moist climatic conditions than arid climatic conditions.

Acknowledgments: The Karadeniz Technical University Scientific Research Foundation (Project No. 2006.118.001.9) partly financially supported this study. The author gratefully acknowledges Prof. Dr. Sadettin Korkmaz for their help.

\section{References}

Akaryalı E, Akbulut K (2016) Constraints of C-O-S isotope compositions and the origin of the Ünlüpınar volcanichosted epithermal $\mathrm{Pb}-\mathrm{Zn} \pm \mathrm{Au}$ deposit, Gümüşhane, NE Turkey. Journal of Asian Earth Sciences 117: $119-134$

Algeo TJ, Maynard JB (2004) Trace-element behavior and redox facies in core shales of Upper Pennsylvanian Kansas-type cyclothems. Chemical Geology 206: 289-318

Aydınçakır E (2014) The petrogenesis of Early Eocene non-adakitic volcanism in NE Turkey: Constraints on the geodynamic implications. Lithos 208-209: 361-377

Benabdelkader Amine Taleb A, Probst J-L, Belaidi N, Probst A (2018) Anthropogenic contribution and influencing factors on metal features in fluvial sediments from a semiarid Mediterranean river basin (Tafna River, Algeria): A multi-indices approach. Science of the Total Environment 626: 899-914

Bollhöfer A, Rosman KJR (2001) Isotopic source signatures for atmospheric lead: the Northern Hemisphere. Geochimica et Cosmochimica Acta 65: 1727-40

Cao J, Wu M, Chen Y, Hu K, Bian L, Wang L, Zhang Y (2012) Trace and rare earth element geochemistry of Jurassic mudstones in the northern Qaidam Basin, northwest China. Chemie der Erde Geocemistry 72: $245-252$

Chakraborty P, Sarkar A, Vudamala K, Naik R, Nath BB (2015) Organic matter-a key factor in controlling mercury distribution inestuarine sediment. Marine Chemistry 173: 302-309

Cheema AI, Liu G, Yousaf B, Abbas Q, Zhou H (2020) A comprehensive review of biogeochemical distribution and fractionation of lead isotopes for source tracing in distinct interactive environmental compartments. Science of the Total Environment 719: 135658

Cheng JL, Shi Z, Zhu YW (2007) Assessment and mapping of environmental quality in agricultural soils of Zhejiang Province, China. Journal of Environmental Earth Science 19: 50-54

Cheng H, Hu Y (2010) Lead (Pb) isotopic fingerprinting and its applications in lead pollution studies in China: a review. Environmental Pollution 158: 1134-1146

Çevik F, Göksu M ZL, Derici OB, Fındık Ö (2009). An assessment of metal pollution in surface sediments of Seyhan dam by using enrichment factor, geoaccumulation index and statistical analyses. Environmental Monitoring and Assessment 152(1-4): 309-317

Das SK, Routh J, Roychoudhury AN, Klump JV (2008) Major and trace element geochemistry in Zeekoevlei, South Africa: a lacustrine record of present and past processes. Applied Geochemistry 23: 2496-2511

Bal Akkoca D, Eriş KK, Çağatay MN, Biltekin D (2019) The mineralogical and geochemical composition of Holocene sediments from Lake Hazar, Elazığ, Eastern Turkey: implications for weathering, paleoclimate, redox conditions, provenance, and tectonic setting. Turkish Journal of Earth Sciences 28: 760-785 
Dokuz A (2011) A slab detachment and delamination model for the generation of Carboniferous high-potassium I-type magmatism in the Eastern Pontides, NE Turkey: The Köse composite pluton. Gondwana Research 19: $926-944$

Doucet FJ, Carignan J (2001) Atmospheric isotopic composition and trace metal concentration as revealed by epiphytic lichens. Atmospheric Environment 35: 3681-90

Du Laing G, Rinklebe J, Vandecasteele B, Meers E, Tack FMG (2009) Trace metal behaviour in estuarine and riverine floodplain soils and sediments: A review. Science of the Total Environment 407(13): 3972-3985

Ettler V, Mihaljevič, M, Komárek M (2004) ICP-MS measurements of lead isotopic ratios in soils heavily contaminated by lead smelting: tracing the sources of pollution. Analytical and Bioanalytical Chemistry 378: $311-7$

Fang X, Peng Bo Song Z, Wu S, Chen D, Zhao Y, Liu J, Dai Y, Tus X (2021) Geochemistry of heavy metalcontaminated sediments from the Four River inlets of Dongting lake, China. Environmental Science Pollution Research https://doi.org/10.1007/s11356-021-12635-0.

Feng YW, Jiang T, Song B, Niu YZ (2017) Geochemical discrimination of Middle Permian sedimentary environment of the Yili Area, the border between China and Kazakhstan. Acta Geologica Sinica 91(4): 942-953

Fu X, Wang J, Chen W, Feng X, Wang D, Song C, Zeng S (2016) Elemental geochemistry of the early Jurassic black shales in the Qiangtang Basin, eastern Tethys: constraints for palaeoenvironment conditions. Geological Journal 51: 443-454

Ghrefat H, Yusuf N (2006) Assessing Mn, Fe, Cu, Zn, and Cd pollution in bottom sediments of Wadi Al-Arab Dam, Jordan. Chemosphere 65(11): 2114-2121

Guitián F, Carballas T (1976) Técnicas de análisis de suelos. Ed. Pico Sacro. Santiago, p. 288.

Güven IH (1993) 1/100.000 scaled geological map series of Turkey. No.57-60. MTA Publication, Ankara

Hansmann W, Köppel V (2000) Lead isotopes as tracers of pollutants in soils. Chemical Geology 171: 123-44

Hernandez L, Probst A, Probst J L, Ulrich E (2003) Heavy metal distribution in some French forest soils: Evidence for atmospheric contamination. Science of the Total Environment 312(1-3): 195-219

Hu J, Li Q, Song C, Wang S, Shen B (2017) Geochemical characteristics of the Permian sedimentary rocks from Qiangtang Basin: constraints for paleoenvironment and paleoclimate. Terrestrial, Atmospheric and Oceanic Sciences 28: 271-282

Hurst RW, Davis TE, Chinn BD (1996) The lead fingerprints of gasoline contamination. Environmental Science and Technology 30: 304A-307A

Ip CC, Li M, Zhang G, Wai OWH, Li YS (2007) Trace metal distribution in sediments of the Pearl River Estuary and the surrounding coastal areas, South China. Environmental Pollution 147: 311-323

Islam MS, Ahmed MK, Raknuzzaman M, Habibullah-Al-Mamun M, Islam MK (2015) Heavy metal pollution in surface water and sediment: A preliminary assessment of an urban river in a developing country. Ecological Indicators 48:282-291

Islam MS, Proshad R, Ahmed S (2018) Ecological risk of heavy metals in sediment of an urban river in Bangladesh. Human and Ecological Risk Assessment 24 (3): 699-720

Jiao W, Ouyang W. Hao F, Lin C (2015) Anthropogenic impact on diffuse trace metal accumulation in river sediments from agricultural reclamation areas with geochemical and isotopic approaches. Science of the Total Environment 536: 609-615 
Jones B. Manning DAC (1994) Comparison of geochemical indices used for the interpretation of palaeoredox conditions in ancient mudstones. Chemical Geology 111: 111-129

Kaygusuz A, Arslan M, Siebel W Şen C (2011) Geochemical and Sr-Nd isotopic characteristics of post-collisional calc-alkaline volcanics in the eastern Pontides (NE Turkey). Turkish Journal of Earth Sciences 20: 137-159

Kaygusuz A, Arslan M, SiebelW, Sipahi F, İlbeyli N (2012) Geochronological evidence and tectonic significance of Carboniferous magmatism in the southwest Trabzon area, eastern Pontides, Turkey. International Geology Review 1776-1800

Kimura H, Watanabe Y (2001) Oceanic anoxia at the Precambrian-Cambrian boundary. Geology 29: 995-998

Komárek M, Chrastný V, Ettler V, Tlustoš P (2006) Evaluation of extraction/digestion techniques used to determine lead isotopic composition in forest soils. Analytical and Bioanalytical Chemistry 385: 110915

Komárek M, Ettler V, Chrastný V, Mihaljevič M (2008) Lead isotopes in environmental sciences: a review. Environmental International 34(4): 562-577

Kushwaha A, Hans N, Kumar S, Rani R (2018) A critical review on speciation, mobilization and toxicity of lead in soil-microbe-plant system and bioremediation strategies. Ecotoxicology Environmental Safety 147: $1035-1045$

Lermi A, Sunkari ED (2020) Geochemistry, risk assessment, and Pb isotopic evidence for sources of heavy metals in stream sediments around the Ulukışla Basin, Niğde, southern Turkey. Turkish Journal of Earth Sciences 29: $1167-1188$

Lewan MD, Maynard JB (1982) Factors controlling enrichment of vanadium and nickel in the bitumen of organic sedimentary rocks. Geochimica et Cosmochimica Acta 46: 2547-2560

Li F, Ma W, Meng F, Diao H (2020) Geochemical characteristics and geological significance of Daohugou Formation at Ningcheng County of Inner Mongolia, Eastern China. Geological Journal DOI: $10.1002 / \mathrm{gj} .4050$

Liao J, Chen J, Ru X, Chen J, Wu H, Wei C (2017) Heavy metals in river surface sediments affected with multiple pollution sources, South China: Distribution, enrichment and source apportionment. Journal of Geochemical Explorer 176: 9-19

Lin C, Yu R, Hu G, Yang Q, Wang X (2016) Contamination and isotopic composition of Pb and Sr in offshore surface sediments from Jiulong River, Southeast China. Environmental Pollutotion 218: 644-650

Lovering TG (1969) Distribution of Minor Elements in Biotite Samples From Felsic Intrusive Rocks as a Tool for Correlation

McManus J (1988) Grain size determination and interpretation. In Techniques in Sedimentology (Ed. M. E. Tucker), pp 63-85. Blackwell, Oxford.

Monna F, Ben Othman D, Luck JM (1995) Lead isotopes and Pb, Zn and Cd concentrations in the rivers feeding a coastal pond (Thau, southern France): constraints on the origin(s) and flux(es) of metals. Science of the Total Environment 166: 19-34

Monna F, Hamer K, Lévêque J, Sauer M (2000) Pb isotopes as a reliable marker of early mining and smelting in the Northern Harz province (Lower Saxony, Germany). Journal of Geochemical Explorer 68(3): 201210

Müller G (1969) Index of geoaccumulation in sediments of the Rhine River. Geolological Journal 2(3): 108-118

Müller G (1981) The heavy metal pollution of the sediments of neckars and its tributary: a stocktaking. ChemikerZeitung 105: 157-164 
N'guessan Y M, Probst J L, Bur T, Probst A (2009) Trace elements in stream bed sediments from agricultural catchments (Gascogne region, S-W France): Where do they come from? Science of the Total Environment 407(8): 2939-2952

Novák M, Emmanuel S, Vile M, Erel Y, Véron A, Pačes T, Wieder RK, Vanecek M, Stepanova M, Brizova E, Hovorka J (2003) Origin of lead in eight European peat bogs determined from isotope ratios, strengths, and operation times of regional pollution sources. Science of the Total Environment 37: 437-45

Orani AM, Vassileva E, Renac C, Schmidt S, Angelidis MO, Rozmaric M, Louw D (2019) First assessment on trace elements in sediment cores from Namibian coast and pollution sources evaluation. Science of the Total Environment 669: 668-682

Patel MM, Adrianne H, Jones R, Jarrett J, Berner J, Rubin CS (2008) International Journal of Circumpolar Health use of lead isotope ratios to identify sources of lead exposure in Alaska natives. International Journal of Circumpolar Health 67: 261-268

Peng B, Tang X, Yu C, Tang C, Yin C, Yang G, Tu X, Liu Q, Yang K (2011) Heavy-metal contamination assessment and $\mathrm{Pb}$ isotopic tracing on source of metals in sediments of the lowermost Xiangjiang River, Hunan Province (P. R. China). Acta Geologica Sinica 85(2): 282-299. (in Chinese with an English abstract)

Peng B, Rate A, Song Z, Yu C, Tang X, Xie S, Tu X, Tan C (2014) Geochemistry of major and trace elements, and $\mathrm{Pb}$ isotopes during weathering of black shales of the lower-Cambrian black shales in central Hunan, China. Applied Geochemistry 51: 191-203

Pinto MMSC, Silva MMVG, da Silva EAF, Dinis PA, Rocha F (2017) Transfer processes of potentially toxic elements (PTE) from rocks to soils and the origin of PTE in soils: a case study on the island of Santiago (Cape Verde). Journal of Geochemical Explorer 183: 140-151

Potra A, Dodd JW, Ruhl LS (20179 Distribution of trace elements and Pb isotopes in stream sediments of the TriState mining district (Oklahoma, Kansas, and Missouri), USA. Applied Geochemistry 82: 25-37

Rabinowitz MB (1995) Stable isotopes of lead for source identification. Journal of Toxicology Clinical Toxicology 33: $649-655$

Raj D, Kumar A, Maiti SK (2019) Evaluation of toxic metal (loid)s concentration in soils around an open-cast coal mine (Eastern India). Environmental Earth Sciences 78: 645

Rana V, Maiti SK, Jagadevan S (2016) Ecological risk assessment of metals contamination in the sediments of natural urban wetlands in dry tropical climate. Bulletin of Environmental Contamination Toxicology 97: $407-412$

Roussiez V, Ludwig W, Probst J-L, Monaco A (2005) Background levels of heavy metals in surficial sediments of the Gulf of Lions (NW Mediterranean): An approach based on 133Cs normalization and lead isotope measurements. Environmental Pollution (Barking, Essex: 1987), 138(1): 167-177

Saydam Ç (2002) Petrographic and Organic Geochemical Properties of Late Cretaceous Sedimentary Deposits in Eastern Pontides. PhD, Karadeniz Technical University, Trabzon, Turkey

Saydam Eker C (2012) Petrography and geochemistry of Eocene sandstones from eastern Pontides (NE Turkey): Implications for source area weathering, provenance and tectonic setting. Geochemistry International 50(8): 683-701

Saydam Eker C (2013) Organic Geochemical Characteristics and Depositional Environments of the Eocene Deposits in the Eastern Black Sea Region, NE Turkey. Energy Sources, Part A: Recovery, Utilization, and Environmental Effects 35: 413-425

Saydam Eker Ç (2017) Geochemical and isotopic characteristics of stream and terrace sediments of the Harsit Stream, NE Turkey. Geochemistry Explorer Environment Analysis 17(4), 279-296. 
Saydam Eker Ç (2020a) Distinct contamination indices for evaluating potentially toxic element levels in stream sediments: a case study of the Harşit Stream (NE Turkey). Arabian Journal of Geosciences 13: 1175

Saydam Eker Ç (2020b) Geochemical differences between bed and terrace sediments of the Harşit Stream (NE Turkey): Implications for mixed source rocks, weathering and mass transfer. Bulletin of Earth Sciences 41(1): $1-29$

Saydam C, Korkmaz S (2008) Source rock characteristics and hydrocarbon potential of the Late Cretaceous deposits in the Eastern Pontides, NE Turkey. Energy Sources, Part A 30:1141-1151

Saydam Eker C, Korkmaz S (2011) Mineralogy and whole rock geochemistry of late Cretaceous sandstones from the eastern Pontides (NE Turkey). Neues Jahrbuch Für Mineralogy-Abhandlungen 188(3): 235-256

Saydam Eker C, Sipahi F, Kaygusuz A (2012) Trace and rare earth elements as indicators of provenance and depositional environments of Lias cherts in Gumushane, NE Turkey. Chemie Der Erde-Geochemistry 72 (2): $167-177$

Saydam Eker Ç, Sipahi F, Özkan Ö, Gümüş MK (2017) Evaluation of potentially toxic element contents and Pb isotopic compositions in Ankara Stream sediments within an urban catchment in central Turkey. Environmental Earth Sciences 647: 1-19

Saydam Eker Ç, Demirkol Kiliç E (2018) Geochemistry of Çoruh River bed sediments in NE Turkey: Implications in weathering-sedimentary cycle, provenance, and metal pollution. Geochemistry International 56 (6): $579-600$

Saydam Eker Ç, Arı UV (2020a) Comparison of sandstone and mudstone with different methods for assessing toxic element contamination in the Early-Middle Jurassic sediments of Gümüşhane (NE Turkey). Environmental Earth Sciences 79: 444

Saydam Eker, C, Arı UV (2020b) Geochemistry of the Middle Jurassic sediments in Gümüşhane, north-eastern Turkey: implications for weathering and provenance. Geological Journal 55: 4954-4976

Seifi M, Mahvi AH, Hashemi SY, Arfaeinia H, Pasalari H, Zarei A, Fazlollah C (2019) Spatial distribution, enrichment and geoaccumulation of heavy metals in surface sediments near urban and industrial areas in the Persian Gulf. Desalin. Water Treatment 158: 130-130

Simonetti P Botté SE, Marcovecchio JE (2017) Occurrence and spatial distribution of metals in intertidal sediments of a temperate estuarine system (Bahı'a Blanca, Argentina). Environmental Earth Sciences 76: 636

Singh P (2010) Geochemistry and provenance of stream sediments of the Ganga River and its major tributaries in the Himalayan region, India. Chemical Geology 269: 220-236

Singh M, Müller G, Singh IB (2002) Heavy Metals in Freshly Deposited Stream Sediments of Rivers Associated with Urbanisation of the Ganga Plain, India. Water, Air, Soil Pollution 141(1): 35-54

Tahri M, Benyaich F, Bounakhla M, Bilal E, Gruffat JJ, Moutte J, Garcia D (2005) Multivariate analysis of heavy metal contents in soils, sediments and water in the region of Meknes (central Morocco). Environmental Monitoring Assessment 102: 405-417

Tang Q, Li L, Zhang S, Zheng L, Miao C (2018) Characterization of heavy metals in coal gangue-reclaimed soils from a coal mining area. Journal of Geochemical Exploration 186: 1-11

Taylor SR, McLennan SM (1985) The Continental Crust: Its Composition and Evolution. Oxford: Blackwell Scientific Publishing. 46.

Teutsch N, Erel Y, Halicz L, Banin A (2001) Distribution of natural and anthropogenic lead in Mediterranean soils. Geochimica et Cosmochimica Acta 65: 2853-64

Tokatlı C, Çiçek A, Köse E, Arslan N, Emiroğlu Ö, Uysal K (2015) Heavy metal accumulations in water, sediment, and some cyprinid species in Porsuk stream (Turkey). Water Environment Research 87: 195-204 
Tomlinson DL, Wilson JG, Harris CR, Jeffrey DW (1980) Problems in the assessment of heavy-metal levels in estuaries and the formation of a pollution index. Helgoländer Meeresuntersuchungen 33(1): 566-575

Topuz G, Altherr R, Kalt A, Satır M, Werner O, Schwarz W (2004) Aluminous granulites from the Pulur complex, NE Turkey: a case of partial melting, efficient melt extraction and crystallization. Lithos 72: 183-207

Topuz G, Altherr R, Siebel W, Schwarz W, Zack T, Hasözbek A, Barth M, Satır M Şen C (2010) Carboniferous High-potassium I-type Granitoid Magmatism in the Eastern Pontides: The Gümüşhane Pluton (NE Turkey). Lithos 116: 92-110

Ullah H, Liu G, Yousaf B, Ali MU, Abbas Q, Zhou C (2017) Combustion characteristics and retention-emission of selenium during co-firing of torrefied biomass and its blends with high ash coal. Bioresource Technology. 245: 73-80

Ustaoğlu F (2020) Ecotoxicological risk assessment and source identification of heavy metals in the surface sediments of Çömlekci stream, Giresun, Turkey. Environmental Forensics doi.org/10.1080/15275922.2020.1806148

Ustaoğlu F, Islam MS (2020) Potential toxic elements in sediment of some rivers at Giresun, Northeast Turkey: A preliminary assessment for ecotoxicological status and health risk. Ecological Indicators 113: 106237

Ustaömer T, Robertson AHF (2010) Late Palaeozoic-Early Cenozoic tectonic development of the Eastern Pontides (Artvin area), Turkey: stages of closure of Tethys along the southern margin of Eurasia. Geological Society, London, Special Publications 340: 281-327

Vd'ačný M, Madzin J, Plašienka D (2019) Geochemical characteristics of the Upper Cretaceous to Lower Eocene sedimentary rocks from the Pieniny Klippen Belt (Western Carpathians, Slovakia): implications for tectonic setting, paleoenvironment and paleoclimate. Geosciences Journal 23 (5): 731-745

Veysseyre AM, Bollhöfer AF, Rosman KJR, Ferrari CP, Boutron CF (2001) Tracing the origin of pollution in French Alpine snow and aerosols using lead isotopic ratios. Environmental Science Technology 35: 4463-9

Vural A (2015) Assessment of metal pollution associated with an alteration area: Old Gümüşhane, NE Black Sea. Environmental Science and Pollution Research 22: 3219-3228

Wang Z, Fu X, Feng X, Song C, Wang D, Chen W, Zeng S (2017) Geochemical features of the black shales from the Wuyu Basin, southern Tibet: implications for palaeoenvironment and palaeoclimate. Geological Journal 52: 282-297

Wedepohl KH (1995) The composition of the continental crust, Geochimica et Cosmochimica Acta 59( 7):12171232

Wu X, Probst A (2021) Influence of ponds on hazardous metal distribution in sediments at a catchment scale (agricultural critical zone, S-W France). Journal of Hazardous Materials doi.org/10.1016/j.jhazmat.2021.125077

Xu L, Lehmann B, Mao J, Nagler TF, Neubert N, Bottcher ME, Escher P (2012) Mo isotope and trace element patterns of Lower Cambrian black shales in South China: multi-proxy constraints on the paleoenvironment. Chemical Geology 318-319: 45-59

Yarincik KM, Murray RW, Lyons TW, Peterson LC, Haug GH (2000) Oxygenation history of bottom waters in the Cariaco Basin, Venezuela, over the past 578,000 years: results from redox-sensitive metals (Mo, V, $\mathrm{Mn}$, and Fe). Paleoceanography 15 593-604

Yousaf B, Liu G, Wang R, Imtiaz M, Rizwan MS, Zia-ur-rehman M, Qadir A, Si Y (2016a) The importance of evaluating metal exposure and predicting human health risks in urban and periurban environments influenced by emerging industry. Chemosphere 150: 79-89 
Yousaf B, Liu G, Wang R, Imtiaz M, Zia-ur-Rehman M, Munir MAM, Niu Z (2016b) Bioavailability evaluation, uptake of heavy metals and potential health risks via dietary exposure in urban-industrial areas. Environmental Science and Pollution Research 1-11

Yousaf B, Liu G, Abbas Q, Wang R, Ubaid Ali M, Ullah H, Liu R, Zhou C (2017) Systematic investigation on combustion characteristics and emission-reduction mechanism of potentially toxic elements in biomassand biochar-coal combustion systems. Applied Energy 208: 142-157

Yousaf B, Liu G, Abbas Q, Ali MU, Wang R, Ahmed R, Wang C, Al-Wabel MI, Usman ARA (2018) Operational control on environmental safety of potentially toxic elements during thermal conversion of metalaccumulator invasive ragweed to biochar. Journal of Cleaner Production 195: 458-469

Zhao Z, Zhao J, Wang H, Liao J, Liu C (2007) Distribution characteristics and applications of trace elements in Junggar Basin. Natural Gas Exploration and Development 30: 30-33. (in Chinese with English abstract). 


\section{FIGURE CAPTIONS}

Fig. 1 Simplified geological map of the eastern Black Sea Region (simplified from Güven et al. 1993) and location map of the study area, 1- Paleozoic metamorphic basement, 2- Paleozoic granites, 3- Jurassic-Lower Cretaceous sequences 4- Upper Cretaceous sedimentary rocks, 5- Upper Cretaceous volcanic rocks, 6- Paleocene volcanosedimentary sequences, 6- Paleocene granites, 7- Eocene volcanic, volcano-clastic rocks, sedimentary sequences, 9- thrust fault, 10. (1 Dağbaşı section (Trabzon), 2 and 3 Çamlıyayla and Evliyatepesi sections (Giresun), 4,5 and 6 Musalla, Pirahmet and Mescitli sections (Gümüşhane)

Fig. 2 Stratigraphic sections of late Cretaceous sequences (modified from Saydam Eker and Korkmaz 2011)

Fig. 3 Box and whisker plots of heavy metal(loid) contents fort he studied sandstones

Fig. 4 Vertical change of heavy metal(loid)s in the sandstone samples, data are average values normalized to UCC (Taylor \& McLennan, 1985)

Fig. 5 Distribution of EF for heavy metal(loid)s of the sandstone samples

Fig. 6 Distribution of Igeo for heavy metal(loid)s of the sandstone samples

Fig.7. Distribution of Pi and PIn for heavy metal(loid)s of the sandstone samples.

Fig. 8. a) Plot of ${ }^{208} \mathrm{~Pb} /{ }^{206} \mathrm{~Pb}$ vs. ${ }^{206} \mathrm{~Pb} /{ }^{207} \mathrm{~Pb}$ in the sandstones and potential source materials, b) $1 / \mathrm{Pb}$ normalized values vs. ${ }^{206} \mathrm{~Pb} /{ }^{207} \mathrm{~Pb}$ ratios indicating the sources and levels of pollution of the sandstones.

Fig. 9. Plots of the principial components (PC1, PC2, PC3) showing four groups of physicochemical parameters and heavy metal(loid)s in the sandstones.

Fig. 10. Plot of $\mathrm{Sc} / \mathrm{Th}$ vs. $\mathrm{Co} / \mathrm{Th}$ of the sandstone samples.

Fig.11. The C-value of the sandstone samples reflecting the paleoclimate. The distinguishing criteria are after Zhao et al. (2007) and Cao et al. (2012).

Fig.12. Plots of various trace element parameters used as paleo-redox proixes for the sandstone samples. Boundaries for different redox environments are from Jones and Manning (1994) and Xu et al. (2012). 
Figures

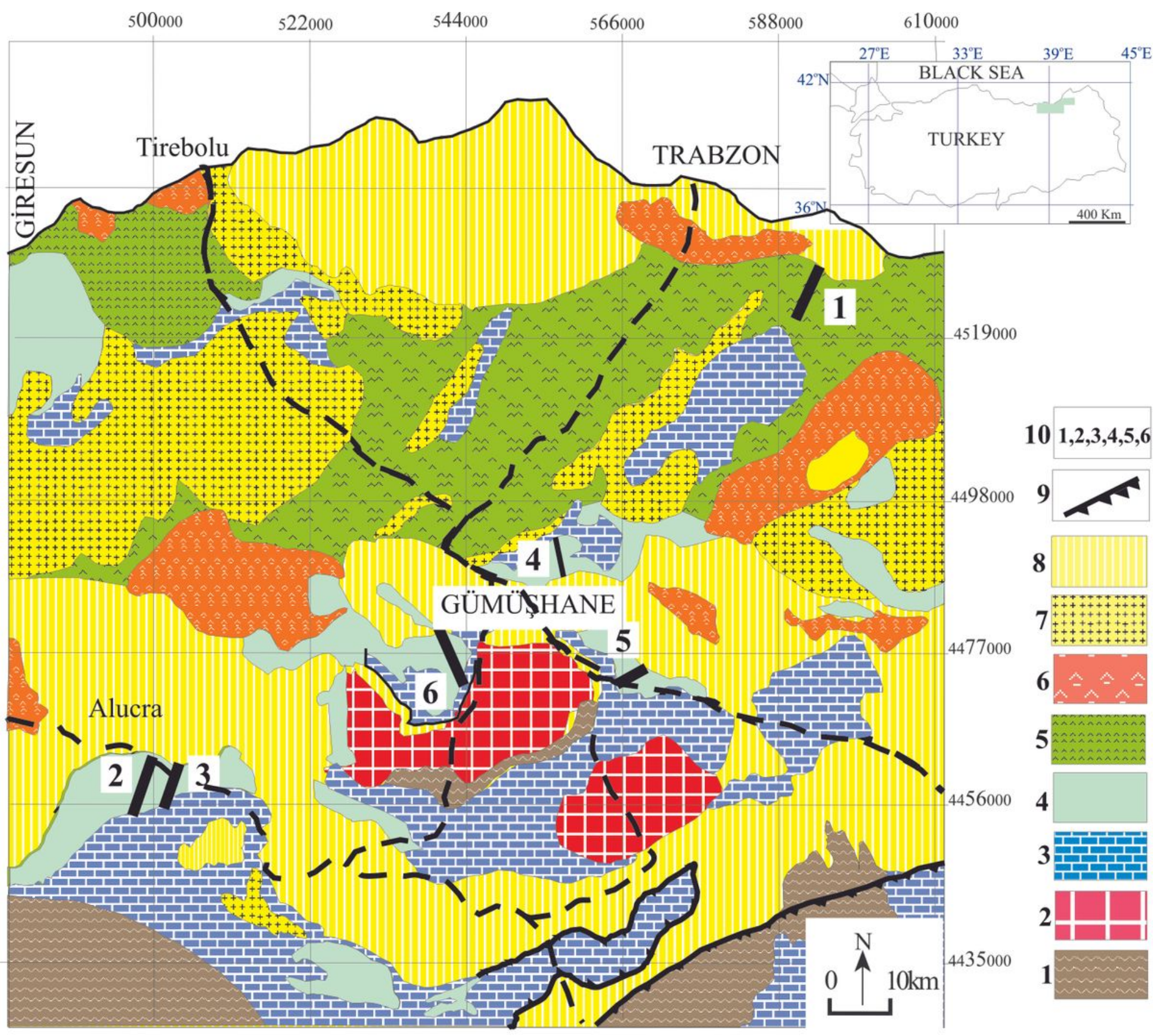

Fig.1

Figure 1

Simplified geological map of the eastern Black Sea Region (simplified from Güven et al. 1993) and location map of the study area, 1- Paleozoic metamorphic basement, 2- Paleozoic granites, 3- JurassicLower Cretaceous sequences 4- Upper Cretaceous sedimentary rocks, 5- Upper Cretaceous volcanic rocks, 6-Paleocene volcano-sedimentary sequences, 6-Paleocene granites, 7- Eocene volcanic, volcano-clastic rocks, sedimentary sequences, 9- thrust fault, 10. (1 Dağbaşı section (Trabzon), 2 and 3 Çamlıyayla and Evliyatepesi sections (Giresun), 4,5 and 6 Musalla, Pirahmet and Mescitli sections (Gümüşhane) Note: 
The designations employed and the presentation of the material on this map do not imply the expression of any opinion whatsoever on the part of Research Square concerning the legal status of any country, territory, city or area or of its authorities, or concerning the delimitation of its frontiers or boundaries. This map has been provided by the authors.

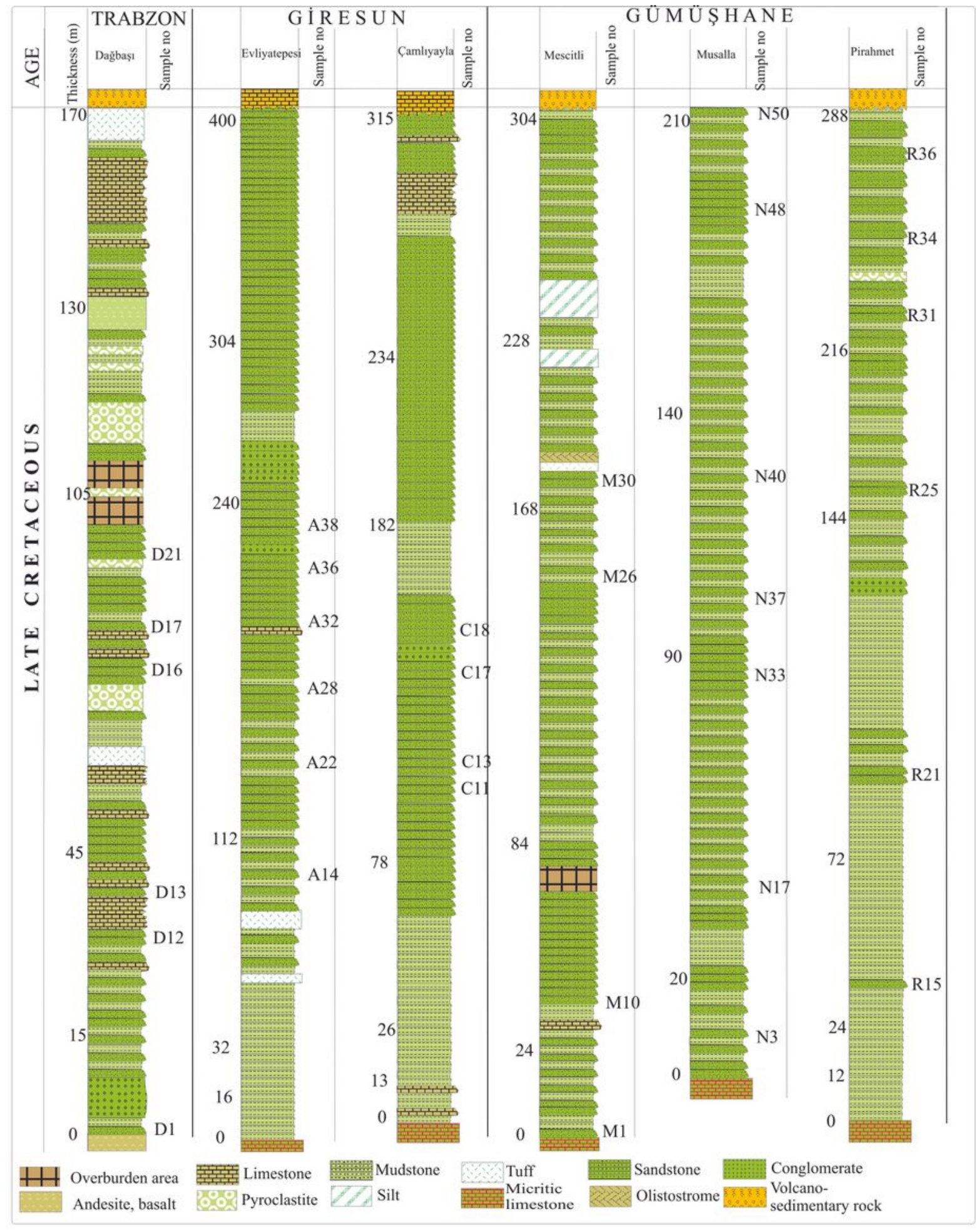

Fig. 2

Figure 2

Stratigraphic sections of late Cretaceous sequences (modified from Saydam Eker and Korkmaz 2011) 

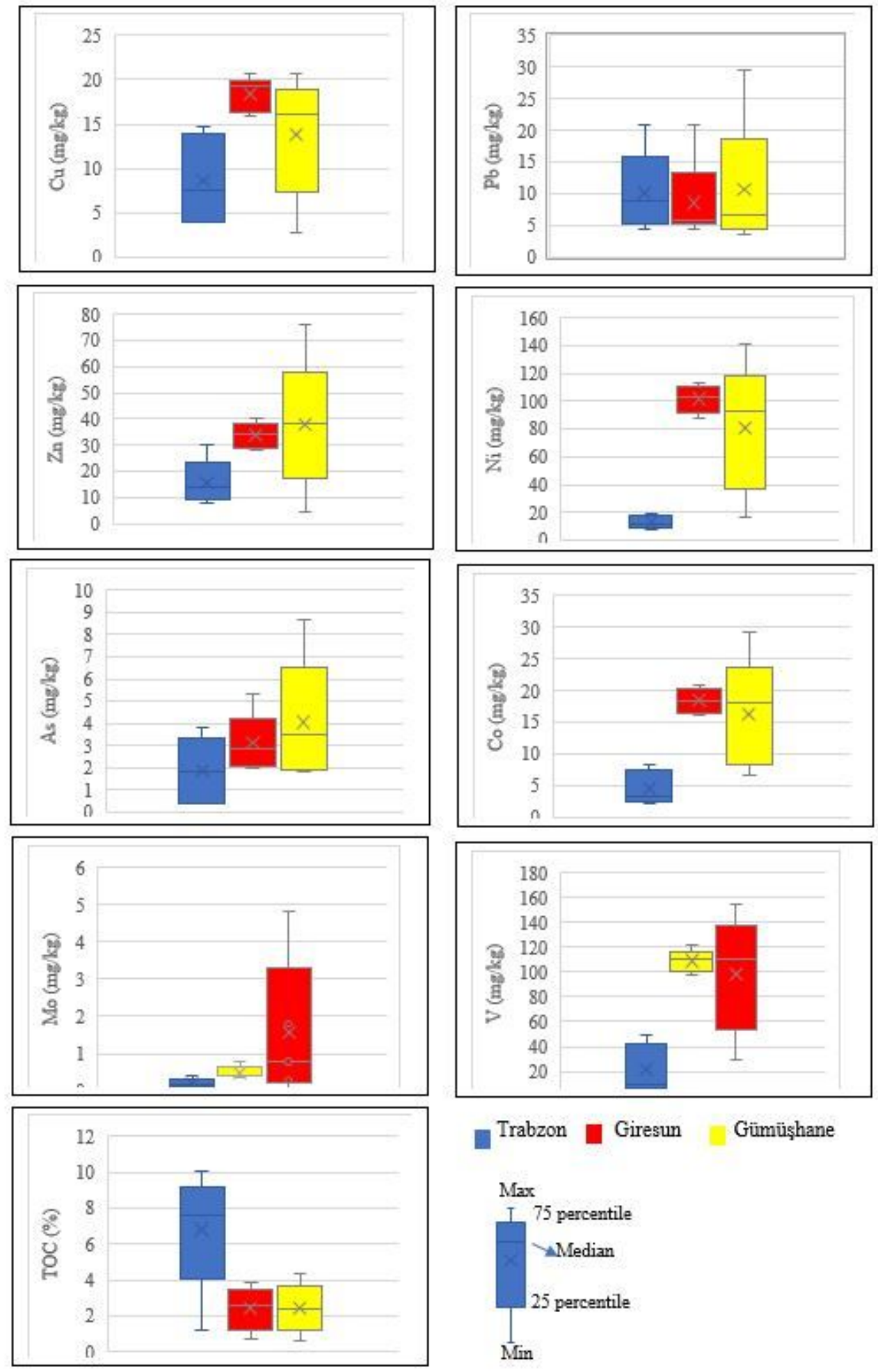

\section{Figure 3}

Box and whisker plots of heavy metal(loid) contents fort he studied sandstones 


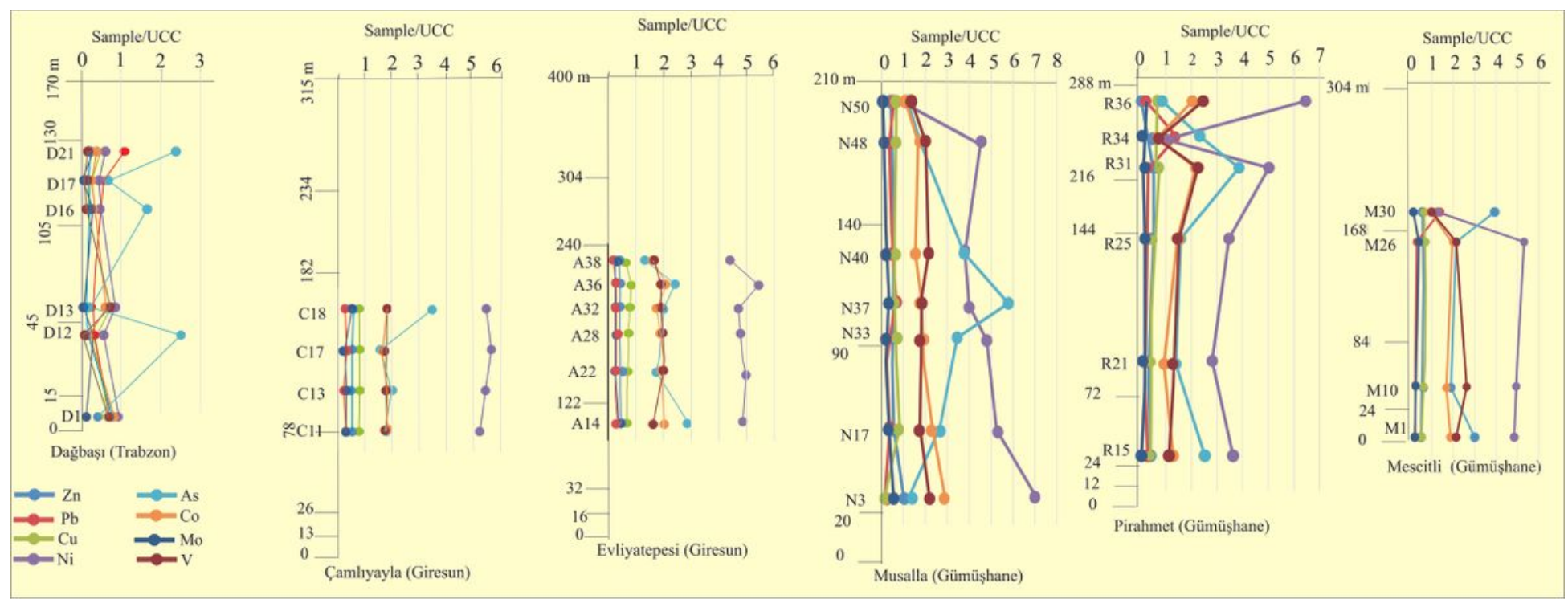

Fig.4

\section{Figure 4}

Vertical change of heavy metal(loid)s in the sandstone samples, data are average values normalized to UCC (Taylor \& McLennan, 1985) 

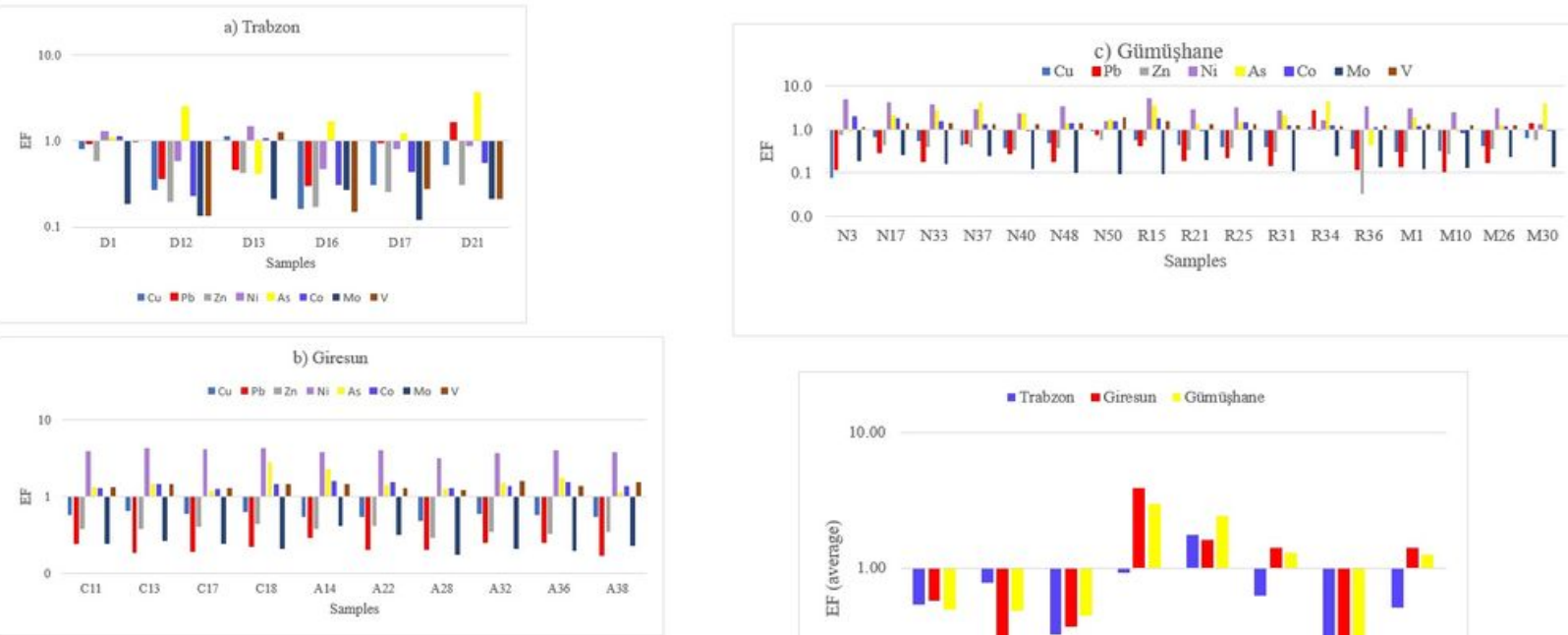

\section{Figure 5}

Distribution of EF for heavy metal(loid)s of the sandstone samples
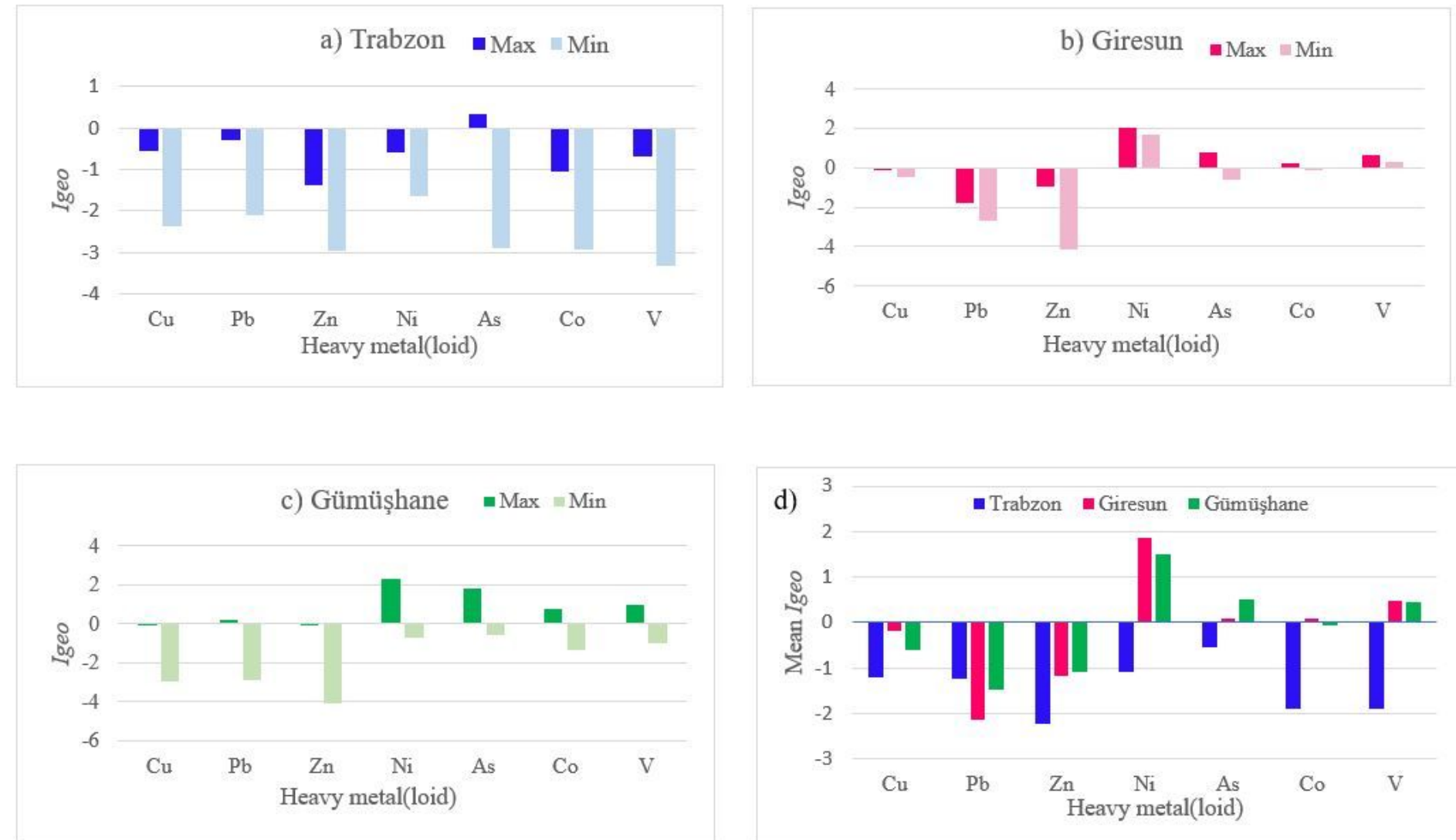

Figure 6 
Distribution of Igeo for heavy metal(loid)s of the sandstone samples
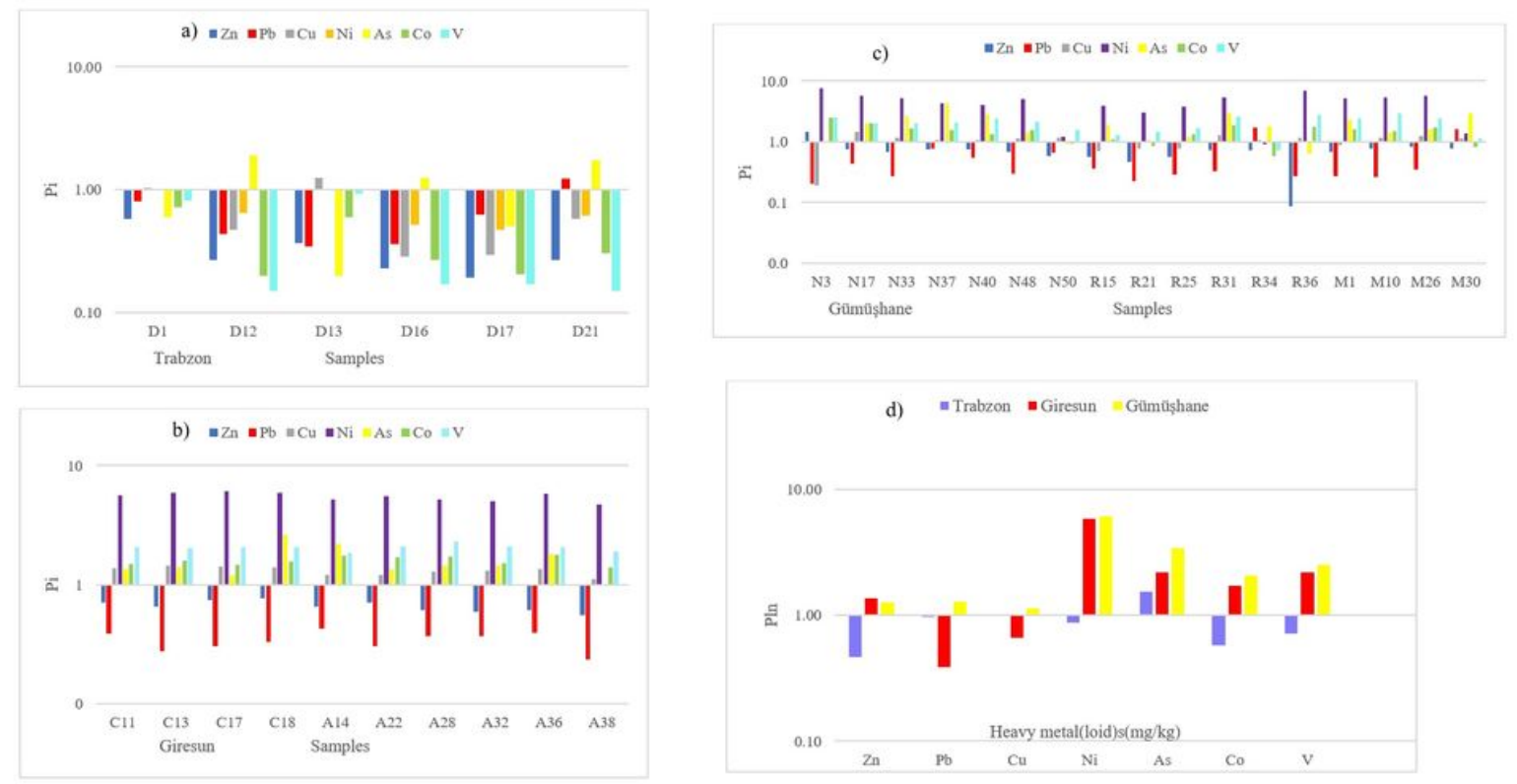

\section{Figure 7}

Distribution of Pi and PIn for heavy metal(loid)s of the sandstone samples. 

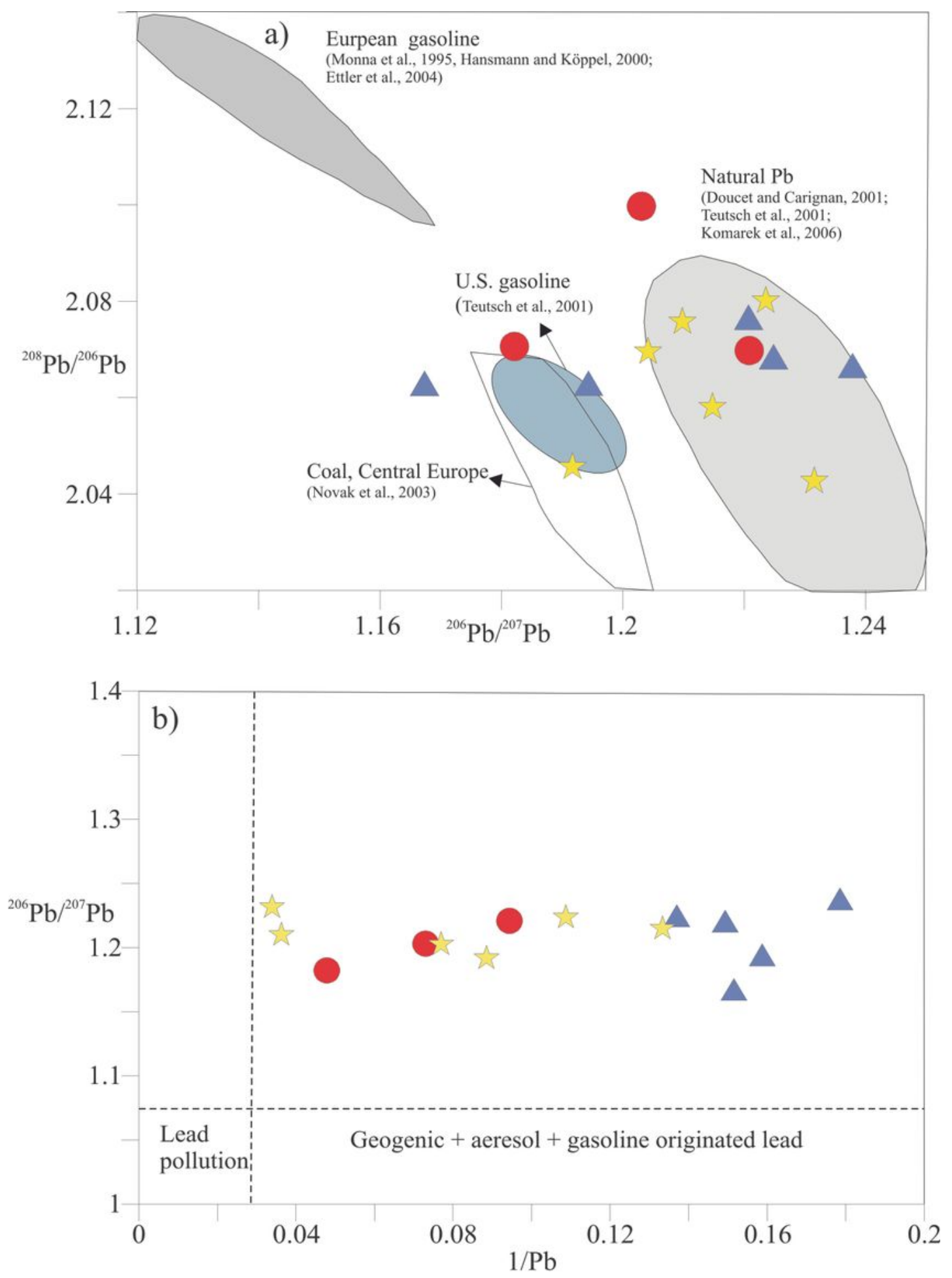

Fig. 8

\section{Figure 8}

a) Plot of $208 \mathrm{~Pb} / 206 \mathrm{~Pb}$ vs. $206 \mathrm{~Pb} / 207 \mathrm{~Pb}$ in the sandstones and potential source materials, b) $1 / \mathrm{Pb}$ normalized values vs. 206 Pb/207Pb ratios indicating the sources and levels of pollution of the sandstones. 

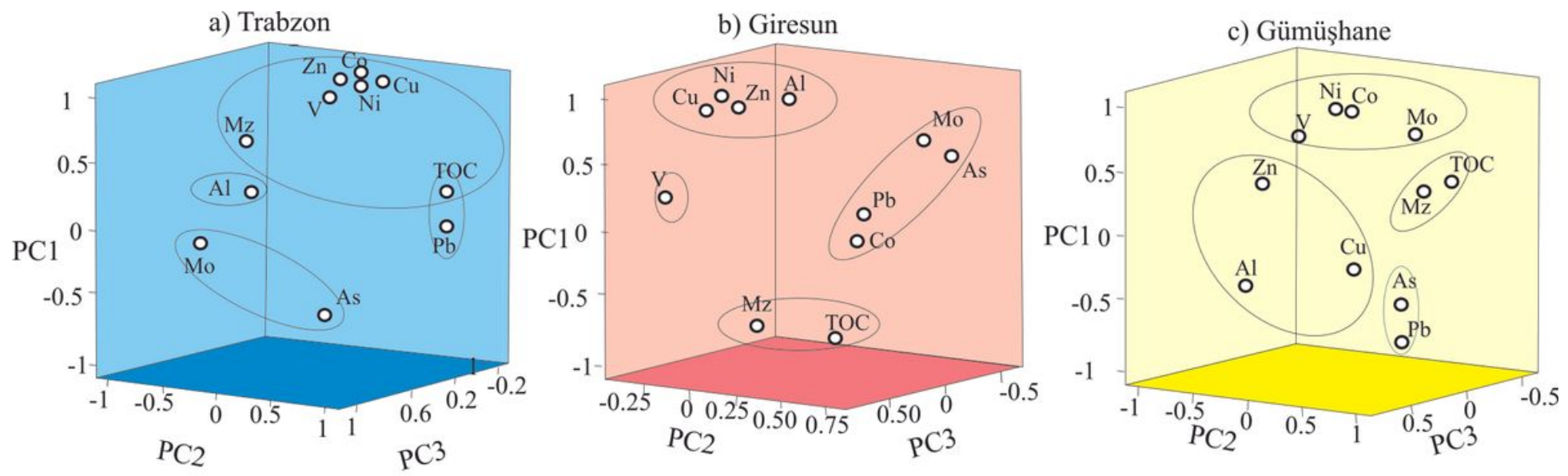

Fig. 9

\section{Figure 9}

Plots of the principial components (PC1, PC2, PC3) showing four groups of physicochemical parameters and heavy metal(loid)s in the sandstones. 


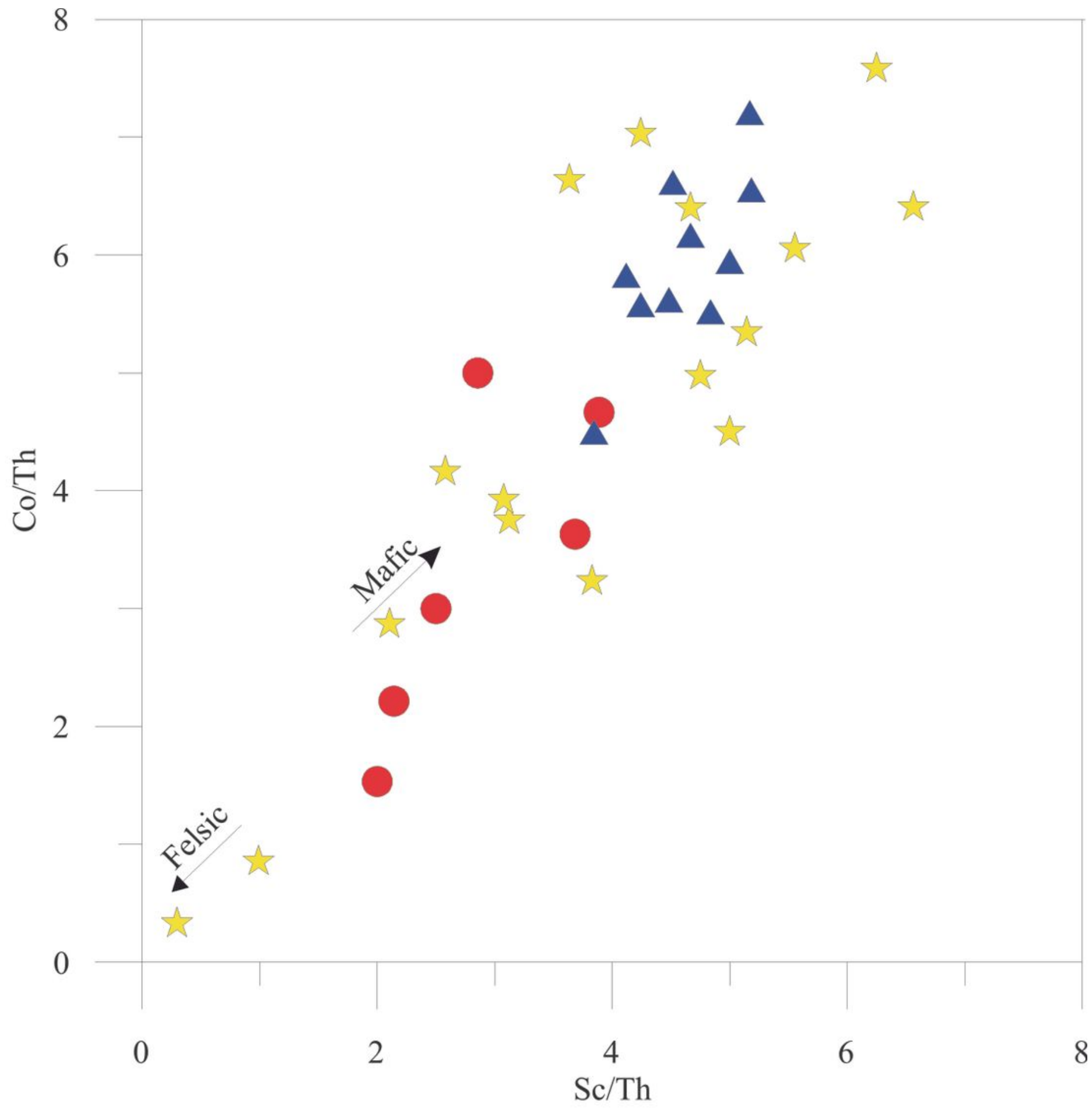

Fig. 10

Figure 10

Plot of Sc/Th vs. Co/Th of the sandstone samples. 


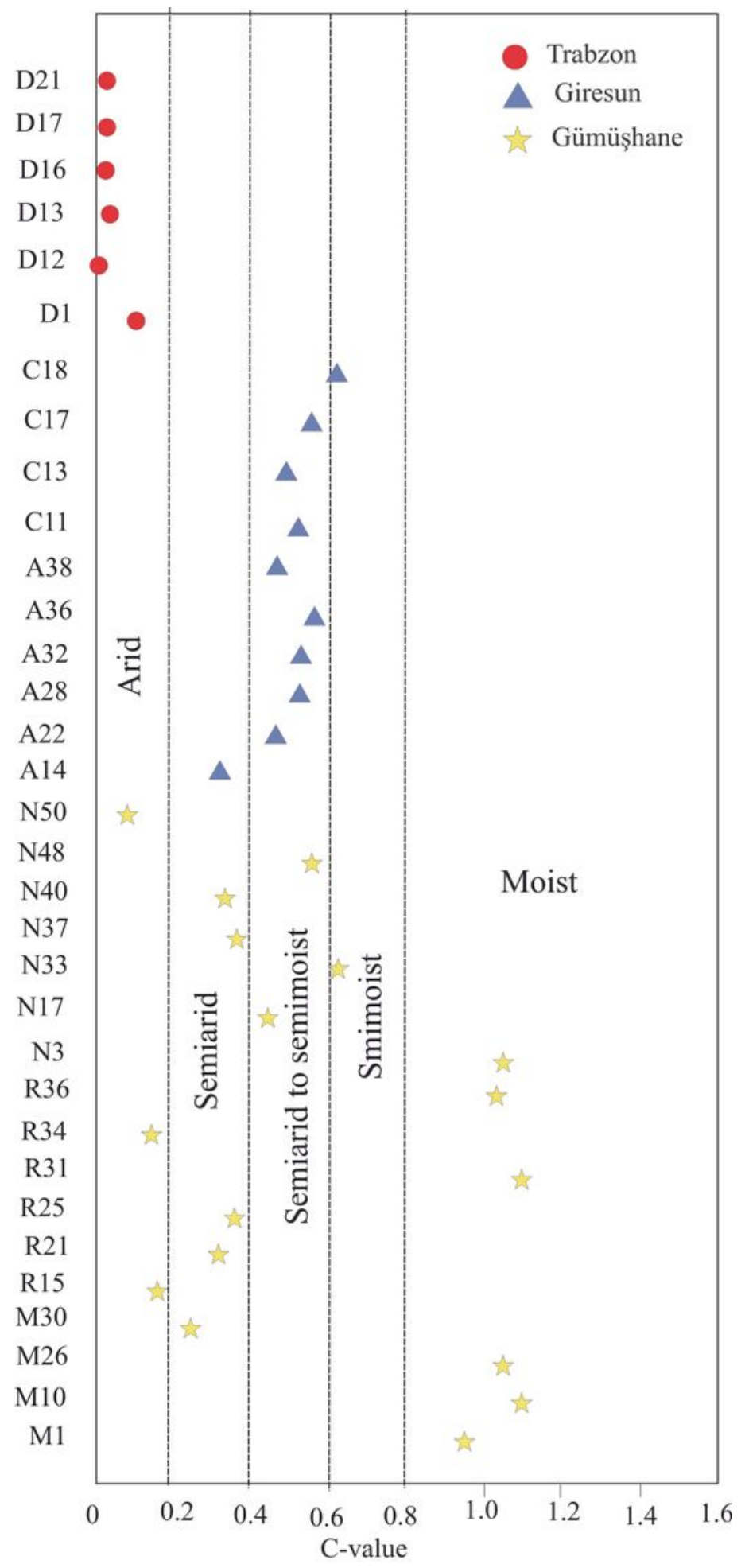

Fig. 11

\section{Figure 11}

The C-value of the sandstone samples reflecting the paleoclimate. The distinguishing criteria are after Zhao et al. (2007) and Cao et al. (2012). 

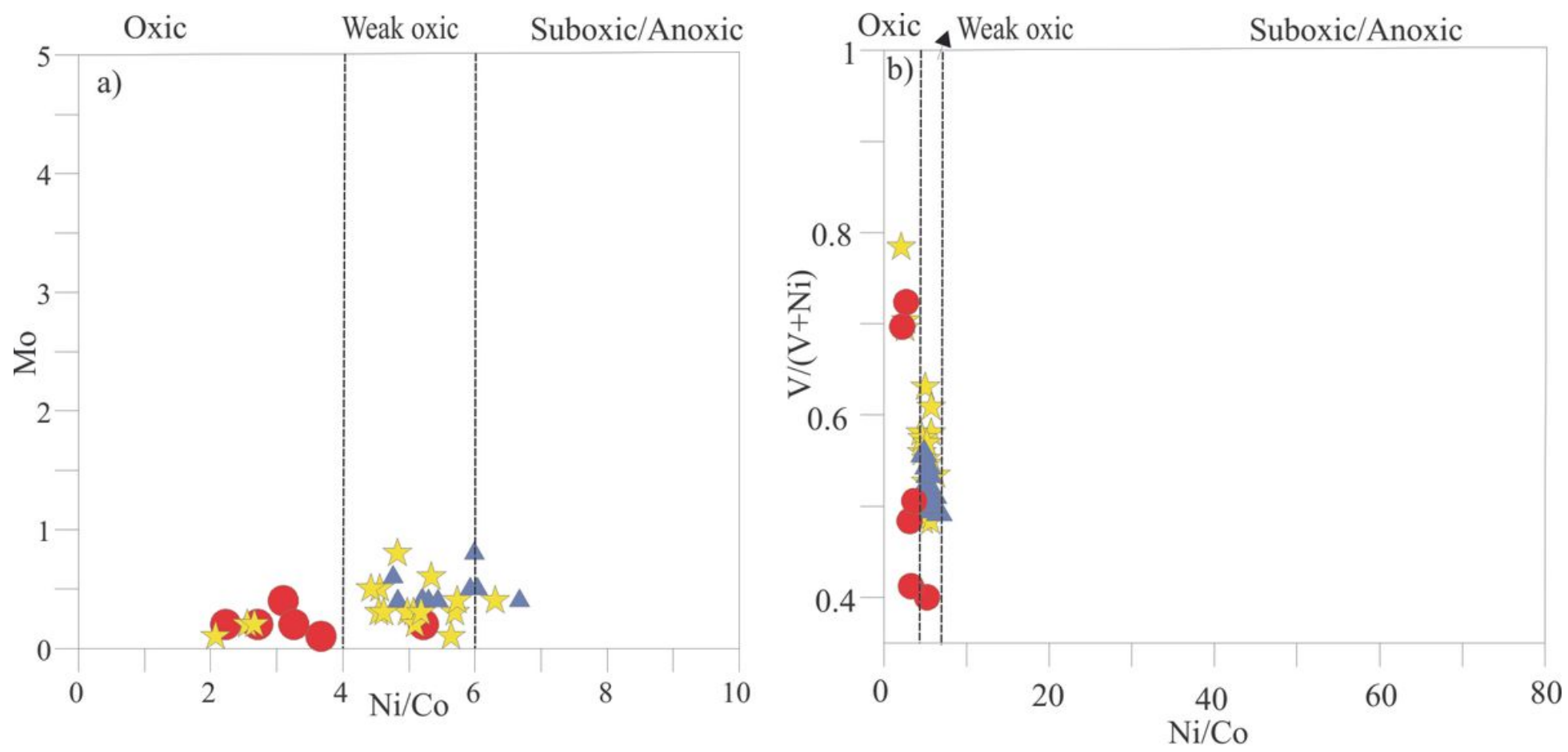

Fig. 12

Figure 12

Plots of various trace element parameters used as paleo-redox proixes for the sandstone samples.

Boundaries for different redox environments are from Jones and Manning (1994) and Xu et al. (2012). 